\title{
NOTE
}

\section{AN EMPIRICAL ANALYSIS OF THE IMPACT OF LEGAL SPORTS BETTING ON CONSUMER CREDIT HEALTH}

\author{
Matthew Q. Clarida*
}

The Supreme Court's May 2018 decision in Murphy v. NCAA removed the federal prohibition against sports betting and invited states to regulate the practice for themselves. This has launched a national debate. Advocates in favor of legal sports betting champion increased tax revenues, business for struggling casinos and racetracks, and regulation of a practice that has flourished in the shadows. Detractors warn of the social ills commonly associated with gambling, including crime, addiction, and financial waste.

This Note provides the first empirical analysis of the impact of legal sports betting on consumer credit health. Making use of the staggered sequencing of state legalization, I find that legal sports betting accounts for a small but statistically significant increase in mortgage delinquency rates. I submit that this finding justifies caution as policymakers explore legal sports betting opportunities.

I. Introduction 1001

II. Four Approaches to Sports Betting Regulation in the United States 1007

A. Federal Regulation After Murphy v. NCAA ..... 1008

B. Conservative Legalization: Class One States... 1011

C. Regulatory Compromise: Class Two States ....... 1014

* J.D. Candidate 2021, Columbia Law School; M.B.A. Candidate 2021, Columbia Business School; B.A., 2016, Harvard College. I thank Eric Talley, Omar Besbes, Andrew Connery, Megan Hirsh, Taylor Sutton, Hannah Koo, and the staff of the Columbia Business Law Review for their comments and suggestions. I am especially grateful to my brother, Russell Clarida, for his guidance and support of me throughout this project. 
D. All In: Class Three States

1017

III. The Empirical Relationship Between Legal Sports Betting and Consumer Credit Health ......................1021

A. Data ............................................................. 1021

B. Methodology.................................................... 1024

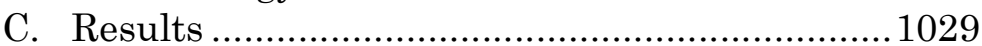

1. The Presence of Legal Sports Betting..........1029

2. The Degree of Legalization .......................... 1034

3. The Amount Wagered................................1038

D. Objections and Limitations .................................1041

1. Technical Issues ......................................... 1042

2. Variable Selection.....................................1044

3. Regulatory Classification ...........................1046

IV. Implications for Policymakers and Researchers ......1047

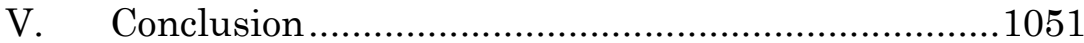

VI. Appendices .......................................................1052

Appendix A: State Betting Totals and Panel Data .1052 Appendix B: Summary Statistics and Fundamental Assumptions...........................................................1064

1. Summary Statistics..................................... 1064

2. Normality Assumption............................... 1065

3. Linearity Assumption................................1067

Appendix C: Regional Classifications.....................1069

\section{INTRODUCTION}

New Jersey Governor Phil Murphy was first in line at the window at Monmouth Park racetrack on June 13, 2018.1 Monmouth, along with New Jersey's two other racetracks and Atlantic City's casinos, had experienced severe economic challenges in recent years. ${ }^{2}$ Any business from the Governor

1 Brent Johnson, Game On! N.J. Sports Betting Kicks Off with Phil Murphy Wager, NJ.COM (last updated Jan. 30, 2019), https://www.nj.com/po litics/2018/06/game_on_nj_sports_betting_kicks_off_with_phil_murp.html [https://perma.cc/VVD3-CJ79].

2 See id. ("New Jersey hopes sports betting will boost the state's struggling casino and horse-racing industries, as well as provide the state with new tax revenue."); see also Kelsey Butler, How Casinos Failed Atlantic City and Why They're Still Part of Its Future, TheStreET (Apr. 13, 
was welcome, but this visit was especially promising. Instead of betting on horses, Murphy wagered $\$ 20$ on Germany to win the FIFA World Cup and another $\$ 20$ on the New Jersey Devils to take the National Hockey League's Stanley Cup. ${ }^{3}$

Murphy was betting on sports, and he was doing so legally. The month prior, in Murphy $v$. NCAA,4 New Jersey had prevailed in its seven-year suit against the federal government. The state successfully alleged that the Professional and Amateur Sports Protection Act (PASPA)5 which effectively prevented states from allowing or facilitating sports betting - was an invalid commandeering of state legislative powers. 6 The Supreme Court's decision to strike down PASPA opened an immediate void. As Justice Samuel Alito wrote for the majority, "Congress can regulate sports gambling directly, but if it elects not to do so, each State is free to act on its own."7

He did not need to ask twice. In the fifteen months following the Murphy decision, New Jersey and eleven other states came to embrace legal sports betting in some form. 8 These states joined Nevada, which has allowed sports betting

2015, 11:17 AM), https://www.thestreet.com/story/13109802/1/how-casinosfailed-atlantic-city-and-why-theyre-still-part-of-its-future.html [https://perma.cc/X67J-WBE4] (describing casino closures).

3 Johnson, supra note 1.

4 Murphy v. Nat'l Collegiate Athletic Ass'n, 138 S. Ct. 1461 (2018).

5 Professional and Amateur Sports Protection Act, Pub. L. No. 102-559, 106 Stat. 4227 (1992), invalidated by Murphy, 138 S. Ct. 1461.

6 See Murphy, 138 S. Ct. at 1470-71, 1478.

7 Id. at $1484-85$.

8 By September 30, 2019, the following states had legal sports betting: Nevada (before Murphy), Delaware (June 2018), New Jersey (June 2018), Mississippi (August 2018), West Virginia (August 2018), New Mexico (by Indian tribes, October 2018), Pennsylvania (November 2018), Rhode Island (November 2018), Arkansas (July 2019), New York (July 2019), Iowa (August 2019), Oregon (by Indian tribes in August 2019, and by State in October 2019), and Indiana (September 2019). See Ryan Rodenberg, United States of Sports Betting: An Updated Map of Where Every State Stands, ESPN (last visited June 9, 2020), https://www.espn.com/chalk/story/_id/ 19740480/the-united-states-sports-betting-where-all-50-states-standlegalization. [https://perma.cc/9E5C-WR9F]. 
at least since 1949 and was exempt from PASPA.9 Together, these thirteen states have embraced a variety of regulatory approaches. Some rolled out the red carpet, with legal inperson and online betting options and few barriers to new players. 10 Others opted for "legalization-lite," issuing sports book operator licenses for in-person gambling only. $11 \mathrm{~A}$ third group of states allowed consumers to bet at physical locations but required them first to register in person to make an online wager. 12 And most of the country-thirty-seven states and Washington, D.C.-still prohibited sports betting as of September 30, 2019.

The different approaches reflect an ongoing national debate. To many, the benefits of legal sports betting are important and obvious. 13 They include new tax revenues (New Jersey earned about $\$ 26$ million from sports betting in the

9 See Jennifer Roberts \& Greg Gemignani, Who Wore It Better? Federal v. State Government Regulation of Sports Betting, 9 U. NeV. Las VEGaS Gaming L.J. 77, 81, 83 (2019); cf. also Ed Vogel, Prison Casino Is History, LAS VEGAS REV. J. (Nov. 26, 2010, 12:00 AM) (discussing briefly gambling in Nevada before 1949), https://www.reviewjournal.com/news/prison-casinois-history/ [https://perma.cc/5JNP-NWSH]

10 See, e.g., Assemb. B. 4111, 218th Leg., Reg. Sess. (N.J. 2018); H.B. 271, 2017 Gen. Assemb., Reg. Sess. (Pa. 2017), https://www.legis.state. pa.us/cfdocs/legis/li/uconsCheck.cfm?yr=2017\&sessInd=0\&act=42 [https://perma.cc/UU43-JDA8].

11 See, e.g., Miss. CoDE. ANN. § 75-76-5(v) (2020) (defining "[1]icensed gaming establishment" as "any premises licensed pursuant to the provisions of this chapter" (emphasis added)); Joe Williams, Mississippi Sports Betting: Is Legal Sports Betting Available in Mississippi?, USA TODAY: SporTSBOOK WIRE (May 2, 2020, 11:00 AM), https://sportsbookwire.usatoday.com/ 2020/05/02/mississippi-sports-betting-is-legal-sports-betting-available-inmississippi/ [https://perma.cc/S9CJ-D82Q].

12 See, e.g., Operation of Gaming Establishments, Nev. Gaming CoMM'N. REG. 5.225(7) (2018), https://gaming.nv.gov/modules/ showdocument.aspx?documentid=2945 [https://perma.cc/TA2P-STQF].

13 Cf. Nick Corasaniti, Move Over, Nevada: New Jersey Is the Sports Betting Capital of the Country, N.Y. TIMEs (June 29, 2019), https://www.nytimes.com/2019/06/29/nyregion/nj-sports-betting.html [https://perma.cc/8QHE-JST8] (summarizing arguments for legalization). 
twelve months following its June 2018 legalization), 14 more business for struggling state race tracks and casinos, 15 and the introduction of some consumer protections to a practice that has flourished in the shadows and been linked to organized crime. 16 But to many others, sports betting-like other forms of gambling - is a dangerous activity accompanied by a range of social ills like addiction, crime, and financial waste. 17

Perhaps because the regulatory changes in the sports betting space are so recent, there has been little empirical investigation into their impact on consumer financial

14 See US Sports Betting Revenue and Handle, LEGAL SporTs ReP. (last updated Dec. 31, 2019, 10:10 AM), https:/www.legalsportsreport.com/

sports-betting/revenue/ [https://perma.cc/3AFV-NKHE]. For convenience, the same data appear infra Part VI app. A.

15 See Corasaniti, supra note 13.

16 Cf. Bennett Baumer, Betting the House: The Mob and Sports Gambling, INDYPENDENT (Jan. 21, 2014), https://indypendent.org/2014/01/

betting-the-house-the-mob-and-sports-gambling/ [https://perma.cc/99SQ$8 Y Z N]$ (discussing the relationship between sports gambling and organized crime).

17 See Sports Betting with a Mobile Component in New York State: Hearing Before the S. Standing Comm. On Racing, Gaming \& Wagering, 2019 Leg., Reg. Sess. 3-4 (N.Y. 2019), https:/www.nysenate.gov/sites/ default/files/ny_council_on_problem_gambling_testimony_5.8.19_sports_be tting.pdf [https://perma.cc/W5S9-HCWT] [hereinafter Sports Betting with a Mobile Component] (statement of James Maney, Executive Director, New York Council on Problem Gambling) (suggesting issues of addiction and crime); cf. also A. Håkansson, Role of Gambling in Payback Failure in Consumer Credit-Data from a Large Body of Material Regarding Consumer Loan Recipients in Sweden, InT'L. J. Env'T. Rsch. \& PUB. HEALTH, Apr. 23, 2020, at 16, https://www.ncbi.nlm.nih.gov/pmc/articles/

PMC7215412/ [https://perma.cc/N5JS-FLDJ] (analyzing the links between gambling and the financial health of Swedish consumers). While there are many justifications for and criticisms of sports gambling, this Note focuses on consumer credit health, because economic data is more widely available than the data required for other analyses. But see generally David Giacopassi \& B. Grant Stitt, Assessing the Impact of Casino Gambling on Crime in Mississippi, 18 AM. J. CRIM. JUST. 117 (1993) (studying empirically the effects of gambling on crime). 
health. 18 This Note takes advantage of the staggered adoption of legalized gambling after Murphy to offer a first attempt.19 It focuses on policy variables germane to the longstanding public debate around gambling, asking how legal sports betting affects consumer credit health. If sports betting visits a substantial drain on financial resources without providing offsetting benefits, legalizing the practice might contribute to negative consumer credit outcomes. 20 One observable proxy for such outcomes is whether or not consumers keep current on their mortgage payments, which are significant monthly obligations for many homeowners.21 This Note's empirical analysis includes nearly ten years of monthly mortgage delinquency rates for each state-nearly 6,000 observations in total. 22 In addition to mortgage data, the empirical analysis uses a novel, comprehensive panel dataset that describes each state's approach to regulating sports betting. 23

18 See Håkansson, supra note 17, at 14 (observing a need for more research on the relationship between gambling and consumer credit).

19 The datasets and models used in this Note are available for replication and cross-checking. Matthew Q. Clarida, Models of Legal Sports Gambling and Consumer Credit Health, Dropbox (last updated Dec. 8, 2020), https://www.dropbox.com/s/zarux001j7var7x/Clarida\%20-\%20Note\% 20Data.xlsm?dl=0 (on file with the Columbia Business Law Review). Readers and researchers are free to utilize these data, provided they cite this Note in doing so.

20 For an example of such outcomes, see Håkansson, supra note 17, at 2 (finding that "short-term and intense gambling, rather than gambling itself, may identify risk of payback failure and risk of indebtedness.").

21 Cf. U.S. Dep't of Hous. \& URB. Dev., Homeowner's Guide to SUCCESS (2018) https://www.hud.gov/sites/dfiles/Housing/documents/

RevUpdHmownSuc121518fnl.pdf [https://perma.cc/X6CS-RTYN] (noting standard payment date for mortgages).

22 See Clarida, supra note 19.

23 For descriptions of the mortgage data, see Press Release, Fed. Hous. Fin. Agency, FHFA and CFPB Partner on Development of National Mortgage Database (Nov. 1, 2012), https:/www.fhfa.gov/Media/ PublicAffairs/Pages/FHFA-and-CFPB-Partner-on-Development-ofNational-Mortgage-Database.aspx [https://perma.cc/MGP4-R8BA]; About the Data, Consumer Fin. Prot. Bureau (last visited Jan. 17, 2020), https://www.consumerfinance.gov/data-research/mortgage-performancetrends/about-the-data/ [https://perma.cc/C47Q-KLBT]. For the regulatory 
I find that legal sports betting is associated with a small but statistically significant increase in mortgage delinquency rates. 24 However, I also find that employment gains from legalization may partially or totally offset this negative effect.25 I submit that these results-while not definitive evidence of cause and effect-suggest causality due to the quasi-experimental setting they reflect.26 I therefore recommend that policymakers prioritize employment gains when implementing legal sports betting. 27 This may be done, to give one example, by routing sports betting through existing casinos and racetracks via regulations which require potential online bettors to visit a casino in order to open an internet gaming account.

The rest of this Note unfolds in three parts. In Part II, I provide an overview of sports betting regulation in U.S. states as of September 30, 2019, the date through which the empirical models used in this Note are current. In Part III, I present these empirical models, explaining the data and methodology I used and showcasing three central models. This Part also includes robustness checks of each model and describes the limitations of my empirical analysis. In Part IV, I use Connecticut, a state considering legalization at the time

data, see Matthew Q. Clarida, Data on State Regulation of Sports Gambling, Dropbox (last updated Sept. 8, 2020), https://www.dropbox.com/s/

8mq4e60d5vz6sj3/Sep\%208\%20Models_v5.xlsm?dl=0 (on file with the Columbia Business Law Review). Readers and researchers are free to utilize these data, provided they cite this Note in doing so.

24 See infra Section III.C.

25 See infra Part IV. Connecticut legislative analysts have identified job growth as a potential benefit of legalized sports betting. Doug Chen \& George Miles, Conn. Off. of Legis. Rsch., Gaming Expansion in Connecticut: What Are the Odds? 9 (2018), https://www.cga.ct.gov/olr/documents/ issuesconf2018/Expansion\%20of\%20Gaming.pdf [https://perma.cc/VT9KVQCG].

26 See infra note 132 and accompanying text; see also JoshuA D. Angrist \& JÖRn-STEFFen PischKe, Mostly Harmless Econometrics: AN EMPIRICIST's COMPANION 38-47 (2008) (discussing causality in statistical inference).

27 See infra Part IV. 
of publication, as a case study to highlight the policy implications of this analysis. A brief conclusion follows.

\section{FOUR APPROACHES TO SPORTS BETTING REGULATION IN THE UNITED STATES}

Justice Louis Brandeis explained in 1932 that "[i]t is one of the happy incidents of the federal system that a single courageous state may, if its citizens choose, serve as a laboratory; and try novel social and economic experiments without risk to the rest of the country."28 Brandeis's observation has proven true in the aftermath of the Supreme Court's decision in Murphy: twelve states legalized sports betting in the fifteen months after the Court ruled.29 This Note analyzes the state of affairs nationwide at the end of this span on September 30, 2019.

Table $1^{30}$

\begin{tabular}{|l|l|l|}
\hline \multicolumn{3}{|c|}{ State Panel Data Classifications, September 2019 } \\
\hline Class & \multicolumn{1}{|c|}{ Criteria } & \multicolumn{1}{c|}{ Membership } \\
\hline \hline 0 & $\begin{array}{l}\text { No legal single-game sports } \\
\text { betting }\end{array}$ & $\begin{array}{l}\text { Thirty-seven states and } \\
\text { D.C. }\end{array}$ \\
\hline 1 & $\begin{array}{l}\text { Legal in-person sports betting, no } \\
\text { online option }\end{array}$ & $\begin{array}{l}\text { DE, MS, IN, NM, NY, } \\
\text { AR, OR }\end{array}$ \\
\hline 2 & $\begin{array}{l}\text { Legal in-person sports betting, } \\
\text { internet sports betting with } \\
\text { registration requirement }\end{array}$ & NV, RI, IA \\
\hline 3 & $\begin{array}{l}\text { Legal in-person and internet } \\
\text { sports betting }\end{array}$ & NJ, PA, WV \\
\hline
\end{tabular}

As Table 1 shows, a diverse group of states has legalized sports betting. These states have advanced regulatory approaches that are also diverse. In this Part, I organize the

28 New State Ice Co. v. Liebmann, 285 U.S. 262, 311 (1932) (Brandeis, J., dissenting).

29 Including Nevada, thirteen states had legalized sports betting by September 30, 2019. See supra note 8.

30 For the data underlying this figure, see Rodenberg, supra note 8. 
fifty states into four regulatory classifications. Class Zero states do not allow any legal sports betting. ${ }^{31}$ Class One states only allow sports betting at brick-and-mortar locations like racetracks and casinos. 32 Class Two states allow in-person sports wagering and internet sports wagering but only with prior in-person registration. 33 Class Three states are the most permissive: in-person sports betting is legal, as is internet sports wagering even without in-person registration. 34 These regulatory classifications are critical not only for understanding the evolving legal landscape but also as inputs to the empirical analysis of Part III.

\section{A. Federal Regulation After Murphy v. NCAA}

As Table 1 makes clear, as of September 30, 2019 most of the country had not acted on Murphy's invitation to legalize sports wagering. 35 While thirteen states allowed sports betting, thirty-seven states maintained their prohibitions. 36 These thirty-seven states are central to this Note's analysis for two reasons. First, they serve as natural comparisons to the states which have legalized, supporting the empirical models in Part III.37 Second, they offer visibility into the

31 Of course, these states have different tribal and illegal gambling environments. These variables present opportunities for further research, see infra Section III.D, but they are largely outside the scope of this Note.

32 See, e.g., ARK. Const. amend. 100, § 3 ("Casino licensees may accept wagers on sporting events[.]” (emphasis added)).

33 See, e.g., Operation of Gaming Establishments, Nev. Gaming. COMM'N REG. 5.225(7) (2018).

34 See, e.g., N.J. STAT. ANN. § 5:12A-11(a)-(b) (West 2020) (establishing licensing scheme without an in-person registration requirement for "sports wagering lounge[s]" offering online sports betting).

35 Gaming laws in U.S. territories are outside the scope of this paper.

36 See supra note 8.

37 See Peter Craig et al., Using Natural Experiments To Evaluate Population Health Interventions: New Medical Research Council Guidance, 66 J. Epidemiology \& CMty. Health 1182, 1183 (2012) (observing the necessity of comparison groups in studies of natural experiments). 
various U.S. laws that regulate gaming activity and remain in place after the Murphy decision. ${ }^{38}$

The Indian Gaming Regulatory Act (IGRA) governs the relationship among tribes, states, and the federal government on gambling issues. 39 Under the IGRA, tribes may offer casino-style gaming-including sports betting-only after agreeing to a detailed regulatory and revenue sharing relationship with the state where they are located. 40 These arrangements may operate as hurdles to legal sports betting today. ${ }^{4}$ In Arizona, for example, the state government cannot legalize sports wagering unless it agrees to a significant reduction in its revenue share with the Pascua Yaqui Tribe or convinces the tribe to modify the compact's terms. 42

Three acts of Congress apply to the transmission of sports wagers or related material between one state where sports betting is legal and another where it is not. The Wire Act forbids the use of "a wire communication facility" to transmit betting information across state or national lines if sports wagering is illegal either at the origin or the terminus of the

38 For a discussion of federal laws providing basline regulation of sports gambling after Murphy even in these thirty-seven states, see Matthew A. Melone, New Jersey Beat the Spread: Murphy v. National Collegiate Athletic Association and the Demise of PASPA Allows for States To Experiment in Regulating the Rapidly Evolving Sports Gambling Industry, 80 U. PITT. L. REV. 315, 318-24 (2018).

39 See 25 U.S.C. $\$ \S 2710-11$ (2018).

4025 U.S.C. $§ 2710$ (d)(1) ("[Sports gambling and certain other] gaming activities shall be lawful on Indian lands only if such activities are ... located in a State that permits such gaming ... [and] conducted in conformance with a Tribal-State compact[.]"); see also Francisco Olea, The Professional and Amateur Sports Protection Act: How Its Invalidation Will Impact Indian Gaming's Legal and Regulatory Framework, 9 U. NEV. LAS VEGAS GAMING L.J. 35, 39-40 (2019).

41 See Olea, supra note 40, at 40-41 (describing a "poison pill" provision in an Arizona arrangement that makes legalization less attractive).

42 See Bureau of Indian Affs., U.S. DeP't of the Interior, Pascua Yaqui Tribe and State of Arizona Gaming Compact § 3(h)(1) (2003), https://www.bia.gov/sites/bia.gov/files/assets/as-ia/oig/pdf/508\%

20Compliant\%202003.02.05\%20Pascua\%20Yaqui\%20Tribe\%20Gaming\%2 0Compact.pdf [https://perma.cc/Q3VY-8H6B]. 
transmission. 43 Similarly, the Travel Act prohibits a person from traveling across state lines in order to further gambling businesses that are illegal in the destination state or under federal law.44 The Interstate Transportation of Wagering Paraphernalia Act prohibits the transport of sports betting materials across state lines, except when the destination state allows sports betting. 45

Two additional acts regulate those who attempt to run sports betting businesses that are not permitted under state law. The Unlawful Internet Gambling Enforcement Act forbids operators from accepting online payments from players attempting to place bets from states that do not allow internet wagering. 46 The Illegal Gambling Business Act levies additional penalties against certain businesses engaged in illegal gaming. 47

These regulations provide the backdrop to legal sports wagering in the United States. Critically, their severe penalties should ensure that legalization efforts in one state are relatively contained to that state's borders-though not necessarily to that state's citizens. 48

4318 U.S.C. $\S 1084(\mathrm{a})-(\mathrm{b})$ (2018). Sanctions include a fine, up to two years in prison, or both. Id. $\S 1084(\mathrm{a})$.

44 Id. $\S 1952(\mathrm{a})(1)-(3)$. Sanctions include a fine, up to five years in prison, or both. Id. § 1952(a)(3)(A).

45 Id. $\S 1953(\mathrm{a})-(\mathrm{b})$. Sanctions include a fine, up to five years in prison, or both. Id. $\S 1953(\mathrm{a})$.

4631 U.S.C. $\S 5363$ (2018). Sanctions include a fine, up to five years in prison, or both. Id. $\S 5366(\mathrm{a})$.

4718 U.S.C. $\S 1955$ (a). Sanctions include a fine, up to five years in prison, or both. Id.

48 See, e.g., Carl Campanile, NJ Is Scoring with Sports BettingThanks to New Yorkers, N.Y. PosT (Jan. 6, 2019, 6:31 PM), https://nypost.com/2019/01/06/nj-is-scoring-with-sports-betting-thanks-tonew-yorkers/ [https://perma.cc/WEY2-8JZY] ("While the Empire State drags its heels on making sports gambling legal, New York residents such as Lou Cangiano are creating their own wheels of fortune by crossing the river to plunk down their bets—-spurring a windfall for the Garden State.”). 


\section{B. Conservative Legalization: Class One States}

\section{Table 249}

\begin{tabular}{|l|c|r|r|}
\hline \multicolumn{4}{|c|}{ State Betting Figures: June 2018 - September 2019 } \\
\hline \multicolumn{1}{|c|}{ State } & Class & 1st Sports Wager & \multicolumn{1}{c|}{ Total Bet } \\
\hline \hline Delaware & 1 & $6 / 5 / 2018$ & $\$ 194,456,807$ \\
\hline Mississippi & 1 & $8 / 1 / 2018$ & $\$ 372,848,295$ \\
\hline New Mexico & 1 & $10 / 16 / 2018$ & No Data \\
\hline Arkansas & 1 & $7 / 1 / 2019$ & No Data \\
\hline New York & 1 & $7 / 16 / 2019$ & No Data \\
\hline Oregon & 1 & $8 / 27 / 2019$ & No Data \\
\hline Indiana & 1 & $9 / 1 / 2019$ & $\$ 35,215,416$ \\
\hline
\end{tabular}

\begin{tabular}{|l|r|r|r|}
\hline \multicolumn{5}{|c|}{ State Betting Figures: June 2018 - September 2019} \\
\hline \multicolumn{1}{|c|}{ State } & Operator Revenue & \multicolumn{1}{c|}{ Tax Revenue } & \multicolumn{1}{c|}{ Tax Rate } \\
\hline \hline Delaware & $\$ 25,826,500$ & $\$ 16,588,554$ & $64.23 \%$ \\
\hline Mississippi & $\$ 40,068,691$ & $\$ 4,808,244$ & $12.00 \%$ \\
\hline New Mexico & No Data & & \\
\hline Arkansas & No Data & & \\
\hline New York & $\$ 3,461,485$ & $\$ 346,149$ & $10.00 \%$ \\
\hline Oregon & No Data & & \\
\hline Indiana & $8,558,974$ & $\$ 813,103$ & $9.50 \%$ \\
\hline
\end{tabular}

Class One states only allow sports betting in person.50 This policy choice has a major impact on the revenue-generating potential of sports betting: consider that New Jersey now earns more tax revenue from internet betting than from inperson wagers. 51 As of September 2019, the Class One states

49 For the first wager dates, see Rodenberg, supra note 8. For the other data underlying this table, see supra note 14. "Tax Rate" refers to the quotient of tax revenue and operator revenue.

50 See supra note 11 and accompanying text.

51 See Katherine Sayre, Mobile Sports Betting Is the Moneymaker as More States Legalize, WALL ST. J. (Sept. 2, 2019, 7:03 PM), https:// www.wsj.com/articles/mobile-sports-betting-is-the-moneymaker-as-morestates-legalize-11567445689 (on file with the Columbia Business Law Review) ("Online gamblers now account for about $80 \%$ of all legal wagers on 
were Delaware, Mississippi, New Mexico, Arkansas, New York, Oregon, and Indiana. 52

Officials in Class One states have cited two primary reasons to limit legal sports betting to brick-and-mortar operations. The first is a desire to drive business to existing casinos and horseracing venues. 53 Delaware became the first

games in New Jersey.”); Devin O'Connor, New Jersey Sports Betting 2019 Handle Totals $\$ 4.58 B$, Generates $\$ 36.5 M$ in Taxes, CASINo.org (last updated Jan. 14, 2020, 4:52 PM), https://www.casino.org/news/new-jerseysports-betting-2019-handle-totals-4b-generates-36m-taxes/ (on file with the Columbia Business Law Review) ("The vast majority of the money wagered [in New Jersey on sports] was facilitated via the internet.").

52 Classifications reflect each state's regulatory approach on September 30, 2019. See DEL. CodE ANN. tit. 29, § 4825 (2020) (authorizing privately managed sports gambling in Delaware); Miss. CoDE. ANN. §§ 75-76-5(v), 89(2) (2020) (authorizing sports gambling on certain Mississippi "premises"); Steve Ruddock, How New Mexico Sports Betting Started in a State Without a Sports Betting Law, Legal Sports ReP. (Nov. 19, 2018), https://www.legalsportsreport.com/26007/pueblo-tribe-new-mexico-sportsbetting/ [https://perma.cc/V7WN-UM65] (describing the initiation of tribal sports betting in New Mexico); ARK. CONST. amend. 100, $§ 3$ (authorizing sports gambling in Arkansas casinos); N.Y. RAC. PARI-MUT. WAG. \& BREED. LAW $\S 1367(2)$ (Consol. 2020) (contemplating sports gambling only at inperson lounges); Don Cazentre, The First Legal Sports Bet in New York State Has Been Placed, NYUP.COM (last updated July 16, 2019), https://www.newyorkupstate.com/casinos/2019/07/the-first-legal-sports-b et-in-new-york-state-has-been-placed.html [https://perma.cc/NGC3-8DMM] (describing initial New York sports betting in a casino); Chinook Winds Casino Opens First Sportsbook Lounge in Oregon, YogoNet (Aug. 28, 2019), https://www.yogonet.com/international/noticias/2019/08/28/50783-chinookwinds-casino-opens-first-sportsbook-lounge-in-oregon

[https://perma.cc/CF4X-2MHC] (describing initial Oregon sports betting in a casino, as well as the possibility for public operation of an online sports betting service); Jabari Young, Oregon Lottery to Launch Sports Betting App Scoreboard with an Expected $\$ 300$ Million in Wagers, CNBC (last updated Oct. 16, 2019, 10:29 AM), https://www.cnbc.com/2019/10/15/oregon-lot tery-to-launch-sports-betting-app-scoreboard.html [https://perma.cc/4RDTLSRZ] (describing Oregon's publicly-run sports betting service); Indiana Sports Betting, LEGAL SPORTS REP. (May 5, 2020, 7:14 PM), www.legalsportsreport.com/indiana/ [https://perma.cc/C7VJ-LLP6] (noting that Indiana betting apps must associate with "land-based entities" and that no apps launched before September 30, 2019).

53 See, e.g., Johnson, supra note 1 (discussing New Jersey's interest in supporting the "casino and horse-racing industries"); CNBC, Delaware 
Class One state on June 5, 2019, and Governor John Carney placed a bet that day. $54 \mathrm{He}$ explained that the state's gambling "legislation ... was designed to reinvigorate the horseracing industry, so I don't expect that we'll take sports betting outside of those three racinos."55 Mississippi has advanced similar justifications, and officials credited sports betting with increasing business at casinos in the state. 56

Advocates and officials in Class One states also have voiced concerns about the collateral consequences associated with gambling, including addiction and financial waste. 57 Thus, in New York, advocates for the state's conservative approach frame sports betting as a new way for "New Yorkers [to] waste

Governor John Carney Talks up Sports Betting in His State, YouTuBE (June 5, 2018), https://www.youtube.com/watch?v=0n3gw_RuVbs (transcript on file with the Columbia Business Law Review) (describing Delaware's interest in supporting the horseracing industry).

54 CNBC, supra note 53.

55 Id.; see also Tom Lehman, Delaware Not Quite Ready for Online Sports Betting, WBOC (last updated Aug. 15, 2019, 7:32 AM), http://www.wboc.com/story/40920059/delaware-not-quite-ready-for-onlinesports-betting [https://perma.cc/RB6F-JVDU]. A racino is a combined casino and racetrack. Cf. Dover Downs' New Owner Offers Upbeat View of Racino's Prospects, Del. Bus. Now! (Aug. 11, 2019), https://delawarebusinessnow .com/2019/08/dover-downs-new-owner-offers-upbeat-view-of-racinosprospects/ [https://perma.cc/6NGF-L7H6].

56 The Associated Press, Mississippi Casinos Win More as Sports Betting Boost Extends, WREG (May 1, 2019, 10:30 AM) (quoting casino managers) https://wreg.com/2019/05/01/mississippi-casinos-win-more-assports-betting-boost-extends/ [https://perma.cc/H9YE-D2SP]. Mississippi does allow limited digital sports betting, but users must be on the campus of a casino that accepts sports bets. See Mary Perez, Mississippi Still the Only State in Southeast with Sports Betting. It's Paying Off, BILOXI SuN HERALD (last updated Feb. 13, 2020, 4:35 PM), https:/www.sunherald .com/news/business/casino-gambling/article239242378.html (on file with the Columbia Business Law Review) (noting that casinos have not exploited the opportunity for on-campus mobile betting).

57 See, e.g., Sports Betting with a Mobile Component, supra note 17, at 3; Errol Louis, Doubling Down on a Bad Bet: With Sports Betting, New York Is Poised To Dig Itself Deeper into Dependence on Problem Gambling, N.Y. DAILY NEws (Mar. 5, 2019, 5:00 AM), https:/www.nydailynews.com/ opinion/ny-oped-doubling-down-on-a-bad-bet-20190304-story.html [https://perma.cc/R55U-MQGP]. 
[their] hard-earned money."58 Others raise the related concern that increased access will contribute to addiction. 59 "What we know to be true in any vice exposure-whether it be substance abuse or gambling - is that increased availability leads to increased participation, which leads to the inevitable increase in problems and consequences," New York advocate James Maney testified before a state committee in May 2019.60

Background law may shape permissiveness as well. New Mexico's government has not acted on sports betting. Tribes within the state, however, have argued that they may offer sports betting under the IGRA because New Mexico does not specifically prohibit it. 61 On October 16, 2018, the Pueblo tribe in Santa Ana accepted its first sports bets at its casino outside Albuquerque. 62 And in Arkansas, sports betting became legal at the state's casinos only after voters approved an amendment to the state constitution. 63

\section{Regulatory Compromise: Class Two States}

\section{Table 364}

\begin{tabular}{|c|c|c|c|}
\hline \multicolumn{4}{|c|}{ State Betting Figures: June 2018 - September 2019 } \\
\hline State & Class & $\begin{array}{c}\text { 1st Sports } \\
\text { Wager }\end{array}$ & Total Bet \\
\hline \hline Nevada & 2 & 1949 & $\$ 6,611,525,650$ \\
\hline
\end{tabular}

58 See Louis, supra note 57.

59 See Sports Betting with a Mobile Component, supra note 17, at 2-3.

60 Id.

61 See Ruddock, supra note 52 ("[I]f a state is allowing its commercial operations to offer sports betting there's no question that the tribe should be able to offer sports betting as well. ... The gray area is where there's no prohibition and there's no outright allowance[.]" (internal quotation marks omitted)).

62 See Santa Ana Star Casino Hotel First To Open Sportsbook in New Mexico, SANTA ANA STAR (Oct. 16, 2018), https://www.santaanastar.com/ press/pressRelease.php?Santa-Ana-Star-Casino-Hotel-First-to-OpenSportsbook-in-New-Mexico-157 [https://perma.cc/4NLM-SXX3].

63 See ARK. Const. amend. 100, § 3.

64 For the sources of these data, see supra note 49. 


\begin{tabular}{|l|r|r|r|}
\hline Rhode Island & 2 & $11 / 26 / 2018$ & $\$ 168,165,611$ \\
\hline Iowa & 2 & $8 / 15 / 2018$ & $\$ 47,285,167$ \\
\hline
\end{tabular}

\begin{tabular}{|l|r|r|r|}
\hline \multicolumn{4}{|c|}{ State Betting Figures: June 2018 - September 2019 } \\
\hline \hline Ntate & Operator Revenue & $\begin{array}{c}\text { Tax } \\
\text { Revenue }\end{array}$ & \multicolumn{1}{|c|}{ Tax Rate } \\
\hline Rhode Island & $\$ 407,741,000$ & $\$ 27,522,521$ & $6.75 \%$ \\
\hline Iowa & $\$ 11,063,195$ & $\$ 5,642,228$ & $51.00 \%$ \\
\hline
\end{tabular}

Class Two states have a ready model. Nevada historically has been known as the gambling capital of the United States.65 Its regulators claim that it accounts for more than half of commercial casino employment in the United States. 66 Employers include the state's 172 sports-wagering licensees. 67 Despite these impressive figures, Nevada strikes a compromise in its regulatory scheme by requiring that new customers visit a casino to register internet sports betting accounts. 68 This policy choice means that it is easier to place sports bets in New Jersey, West Virginia, and Pennsylvania than in Nevada. 69 But this approach also preserves the central role of casinos-and casino employment-in Nevada sports betting.

65 See Jennifer Roberts \& Abigayle Farris, History of Gambling in Nevada, CommuniquÉ, Nov. 2017, at 28-29 [https://perma.cc/E7RB-6QZU].

66 See Nev. Gaming Control BD. \& Nevada Gaming Comm’n, BoArd INFORMATION PACKET (2020). https://gaming.nv.gov/modules/showdocument .aspx?documentid=14995 [https://perma.cc/74BR-VPFG].

67 Nev. Gaming Control BD. \& Nevada Gaming Comm’n, supra note 66, at 27 tbl.Slot Devices and Table Games.

68 Nev. Gaming Comm’n Reg. 5.225(7) (2018).

69 See Weston Blasi, New Jersey Passes Nevada in Sports Gambling Should Las Vegas Be Worried?, MARketWATch (Nov. 9, 2019, 11:18 AM), https://www.marketwatch.com/story/new-jersey-passed-nevada-in-sportsbetting-last-month-should-las-vegas-be-worried-2019-11-04 [https://perma.cc/V8WF-JERZ] (attributing in significant part New Jersey's advantage over Nevada in monthly betting totals to "the state's support for mobile betting"). For further discussion of these permissive states, see infra Section II.D. 
Nevada's regulatory apparatus is robust. The Nevada Gaming Commission (NGC) and Nevada Gaming Control Board (NGCB) regulate gambling, including sports betting, within the state. 70 Their regulations cover everything from the amount of required reserves an operator must hold $(\$ 25,000$ at minimum) to which types of bets may be accepted (most professional and amateur sports bets) to whether bettors may pay by credit card (generally no). 71

Nevada's deep history with sports betting has made it an attractive template for new entrants. 72 "Nevada has had legal, regulated sports wagering for several decades and the lessons learned from this experience can help guide states or tribes looking to authorize sports wagering," advise two practitionerprofessors. 73 Recently, Iowa has accepted this advice. The state legalized sports betting in August 2019, requiring inperson registration before customers could use the internet to wager. 74

In early September 2019, Rhode Island also decided to follow Nevada's lead 75 and moved from Class One legalization to Class Two legalization after becoming the first state to lose

70 See Nev. Gaming Control Bd. \& Nevada Gaming Comm’n, supra note 66 , at $6-7$.

71 See Nev. Gaming Comm’n REg. §§ 22.040(1), 22.060(1), 22.120 (West 2020).

72 See Roberts \& Farris, supra note 65, at 1 ("Nevada [is] one of the largest tourist destinations in the world with the 'gold standard' of regulated casino gambling.").

73 Roberts \& Gemignani, supra note 9, at 98.

74 See Danny Lawhon, Iowa Sports Betting: What To Do Now That It's Legal To Wager, Des Moines REg. (last updated Aug. 15, 2019, 2:16 PM) (discussing in-person registration requirement for mobile wagering and noting that Iowa's tax rate on wagers is the lowest in the country, equaling Nevada's), https:/www.desmoinesregister.com/story/sports/2019/07/30/ iowa-sport-betting-start-date-legal-sports-gambling-app-ncaa-collegefootball-spread-rule-how-to-bet/1857134001/ [https://perma.cc/R6L3-2CT2]; IowA CoDE $§ 99 \mathrm{~F} .9$ (2020) (allowing online sports betting after in-person registration).

75 See Rhode Island Launches Mobile Sports Betting Application, THE Associated PRESS (Sept. 5, 2019), https://apnews.com/290b32670d0743eab 674fe0ea370d6b8 [https://perma.cc/J62V-GGLG]; S. 0037, 2019 Gen. Assemb., Jan. Sess. (R.I. 2019). 
money in a month of accepting sports bets.76 In February 2019 , the state incurred $\$ 450,000$ in losses after its operating partner lost more than $\$ 2,000,000$ in Super Bowl wagers. 77 The local New England Patriots won the game. 78

\section{All In: Class Three States}

\section{Table 479}

\begin{tabular}{|c|c|c|c|}
\hline \multicolumn{4}{|c|}{ State Betting Figures: June 2018 - September 2019 } \\
\hline State & Class & $\begin{array}{c}\text { 1st Sports } \\
\text { Wager }\end{array}$ & Total Bet \\
\hline \hline New Jersey & 3 & $7 / 14 / 2018$ & $\$ 4,221,819,662$ \\
\hline West Virginia & 3 & $8 / 30 / 2018$ & $\$ 172,119,683$ \\
\hline Pennsylvania & 3 & $11 / 15 / 2018$ & $\$ 607,540,069$ \\
\hline
\end{tabular}

\begin{tabular}{|l|r|r|r|}
\hline \multicolumn{4}{|c|}{ State Betting Figures: June 2018-September 2019} \\
\hline State & Operator Revenue & $\begin{array}{l}\text { Tax } \\
\text { Revenue }\end{array}$ & Tax Rate \\
\hline \hline New Jersey & $\$ 284,634,664$ & $\$ 37,052,658$ & $13.02 \%$ \\
\hline West Virginia & $\$ 17,921,582$ & $\$ 1,792,160$ & $10.00 \%$ \\
\hline Pennsylvania & $\$ 57,101,862$ & $\$ 16,411,010$ & $28.74 \%$ \\
\hline
\end{tabular}

Class Three states have the fewest regulatory barriers to legal sports betting. New Jersey, West Virginia, and

76 See infra Part VI app. A.

77 See Patrick Anderson, Gambling Problem: R.I. Sports Betting Operation Lost $\$ 900 K$ Last Month, Providence J. (last updated Mar. 29, 2019, 2:23 PM), https://www.providencejournal.com/news/20190329/gambli ng-problem-ri-sports-betting-operation-lost-900k-last-month [https://perma.cc/CXQ3-2ED8] (describing Super Bowl losses); see also infra Part VI app. A (describing lost tax revenues).

78 Anderson, supra note 77.

79 For the sources of these data, see supra note 49; Andrew Maykuth, Hollywood Casino Is First To Launch Legal Sports Betting in Pa., PHILA. INQUIRER (last updated Nov. 15, 2018, 5:47 PM), https://www.inquirer.com/ philly/business/tourism_casinos/valley-forge-applies-for-pa-sports-bettinglicense-parx-sugarhouse-harrahs-20181115.html [https://perma.cc/D2TPKBZ9]. 
Pennsylvania allow not only brick-and-mortar sports betting but also internet sports betting without in-person registration. $80 \mathrm{~A}$ prospective mobile bettor needs only a social security number, checking account, physical presence within a Class Three state, and about ten minutes to place a legal wager. 81 This ease makes sports betting more available to state residents and short-term travelers across state lines. 82

New Jersey became the first Class Three state in July 2018. The state requires internet sports betting operators to affiliate with brick-and-mortar locations, evidencing some desire to use sports betting to support racetracks and casinos.83 By November 2019, it had ten licensed and operating "Sports Wagering Lounges," each anchored at a casino or racetrack. 84 However, it is unclear if New Jersey's affiliation rules drive casino employment, especially since mobile gaming made up the majority of 2019 sports wagers in the state and fueled rapid revenue growth. 85

80 See N.J. STAT. ANN. § 5:12A-11(e) (West 2020) (allowing in-person and mobile sports betting); W. VA. CoDE $§ 29-22 D-15$ (a)-(b) (2020) (same); 4 PA. Cons. STAT. § 13C21(a) (same).

81 See Campanile, supra note 48 (illustrating the low barriers to sports gambling in New Jersey); Frequently Asked Questions, DRAFTKINGs (last visited Oct. 13, 2020), https://sportsbook.draftkings.com/help/faq [https://perma.cc/C7GK-YRZK] (discussing geolocation and social security requirements).

82 See, e.g., Campanile, supra note 48.

83 See N.J. STAT. ANN. § 5:12A-11(a)-(b) (West 2020) (permitting sports betting licenses for casinos and racetracks and authorizing licensees to launch or sponsor mobile sports wagering applications); Nick Corasaniti, How a New Jersey Sports Bar Made a $\$ 3$ Million Bet and Won, N.Y. Times (May 23, 2018), https://www.nytimes.com/2018/05/23/nyregion/in-newjersey-a-3-million-bet-that-a-sports-bar-could-take-bets.html [https://perma.cc/386N-PKNC] (discussing possible effects on the Monmouth racetrack).

84 N.J. Div. Gaming EnF'T, Sports Wagering, N.J. OfF. of The AтT'Y GEN. (last visited Nov. 24, 2019), https://www.nj.gov/lps/ge/sportsbetting.ht $\mathrm{ml}$ [https://perma.cc/6KPA-XUDZ].

85 See Corasaniti, supra note 83 (discussing the need for racetracks to attract mobile users to compete); O'Connor, supra note 51 (describing the scale of mobile betting in New Jersey). 


\section{Figure 186}

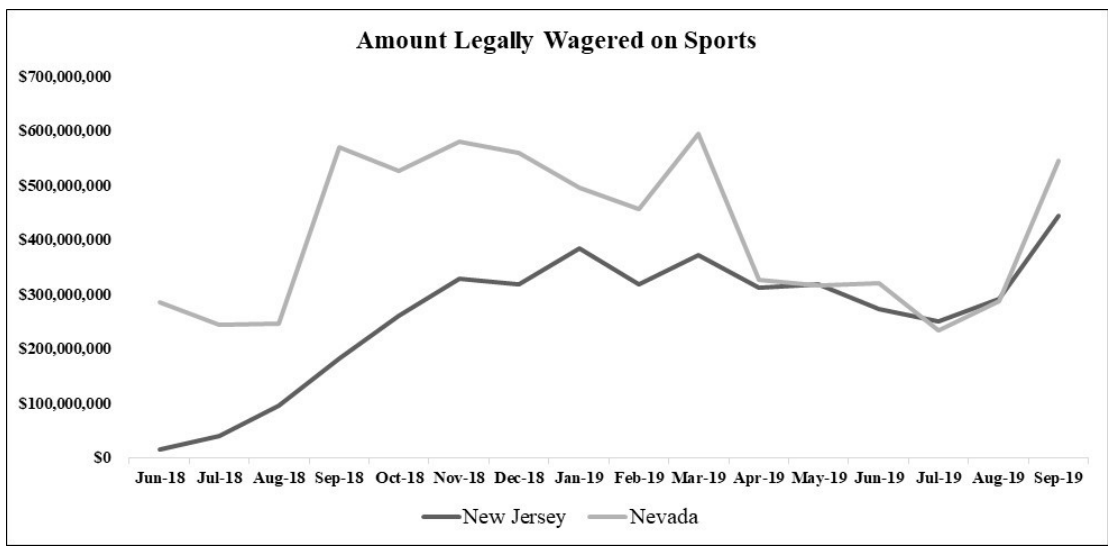

Within a year of legalization, New Jersey approached Nevada's popularity as a sports betting center, highlighting the revenue opportunities available to states that facilitate online sports gambling. 87 In 2019, eighty-four percent of New Jersey's sports betting handle came from mobile wagers. 88

New Jersey's success has turned heads, and other states have followed its lead. Pennsylvania legalized sports betting in November 2018 as a Class One state, offering only inperson betting. 89 In May 2019, however, the state legalized

86 For the sources of these data, see supra note 49. "Handle" refers to the amount wagered.

87 See Darren Rovell, New Jersey 2019 Sports Betting Handle, Revenue, Taxes \& More, The ACTion Network (Jan. 14, 2020, 6:41 PM), https://www.actionnetwork.com/news/new-jersey-sports-betting-2019handle-revenue-taxes [https://perma.cc/KV8L-NY5T].

88 Id. As in Class One states, New Jersey advocates worry about the collateral consequences of easy access to sports betting. See Carl Campanile, NJ Addiction Experts Warn NY on Dangers of Online Sports Betting, N.Y. Post (Dec. 8, 2019, 9:03 PM), https://nypost.com/2019/12/08/nj-addictionexperts-warn-ny-on-dangers-of-online-sports-betting/ [https://perma.cc/Q2V2-86EX] (reporting such worries).

89 See Andrew Maykuth \& Ed Barkowitz, SugarHouse Becomes First Pennsylvania Casino To Launch Internet Sports Betting, PHILA. INQUIRER (last updated May 28, 2019), https://www.inquirer.com/news/sugarhousecasino-first-launch-internet-sports-betting-pennsylvania-20190528.html [https://perma.cc/5FHK-YCVN]. 
internet sports betting without an in-person registration requirement,90 although operators were still required to associate with brick-and-mortar casinos.91 The result has been a rapid increase in the total amount of sports wagers, as Figure 2 shows.

Figure $2^{92}$

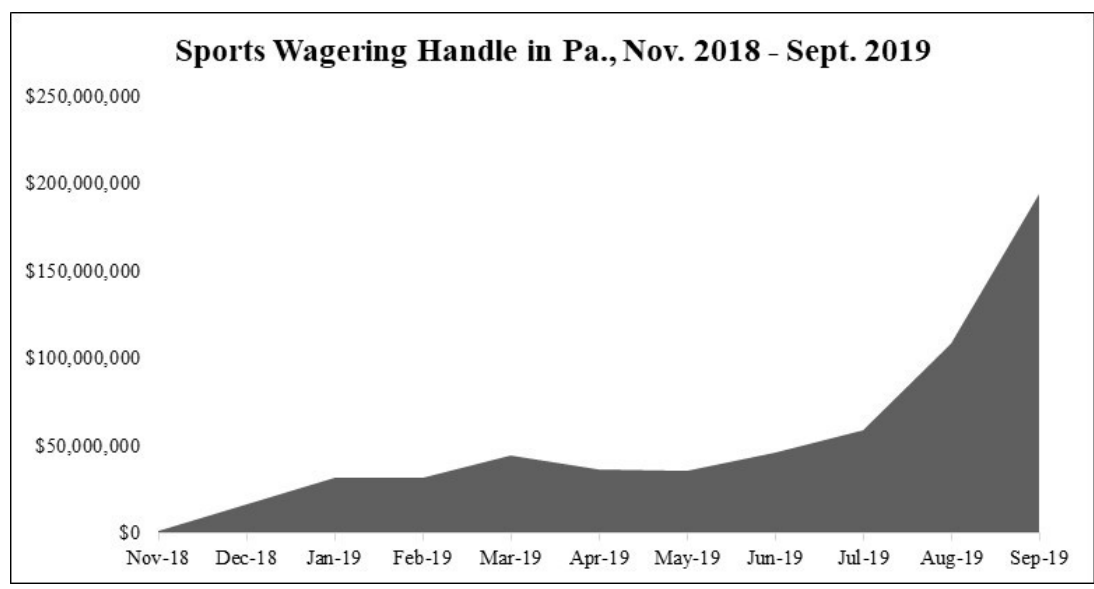

Other states are increasingly exploring the Class Three approach. After experiencing technical issues for weeks with its online betting platform, West Virginia welcomed back internet sports betting by August 2019.93 More states have

90 See id.

91 See 4 PA. Cons. STAT. § 13C11(a) (allowing even online sports wagering operations only from holders of slot machine licenses); id. § 1301 (tying slot machine licenses to physical facilities).

92 For the sources of these data, see supra note 49.

93 See Eric Ramsey, Delaware North Splits with Miomni over WV Sports Betting Dispute, LEGAL SpoRTs REP. (last updated Apr. 10, 2019, 9:26 AM), https://www.legalsportsreport.com/30800/delaware-north-miomnitermination/ [https://perma.cc/8MMC-A8R8] (describing a dispute that hampered earlier online sports betting); Press Release, Fanduel Grp., FanDuel Group Debuts New Sports Betting Experience in West Virginia (Aug. 26, 2019), https://newsroom.fanduel.com/2019/08/26/fanduel-groupdebuts-new-sports-betting-experience-in-west-virginia/ [https://perma.cc/E7XA-ZNQV] (announcing the launch of a West Virginia sports betting app with no in-person registration requirement). 
joined Class Three since. Indiana, which legalized as a Class One state in September 2019, began accepting online bets in October 2019.94 Oregon sports betting began at a single tribal casino in August 201995 and expanded to a mobile app in October 2019.96 New Hampshire took its first bet on December 30, 2019.97

\section{THE EMPIRICAL RELATIONSHIP BETWEEN LEGAL SPORTS BETTING AND CONSUMER CREDIT HEALTH}

This Part examines the impact of legal sports betting on consumer credit health. Section III.A describes the analyzed datasets, and III.B details the methodology. Section III.C presents three regression models-accompanied by robustness checks-that estimate the relationship between legal sports betting and mortgage delinquency rates, a proxy for consumer credit health. Section III.D closes by describing the limitations of my approach.

\section{A. Data}

This Note's research question is simple: does legal sports betting impact consumer credit health? The dependent variable is each state's monthly mortgage delinquency rate

94 See Indiana Sports Betting, supra note 52.

95 See Chinook Winds Casino Opens First Sportsbook Lounge in Oregon, supra note 52.

96 See Young, supra note 52 (describing the launch of the app); cf. also Oregon Sports Betting, Legal Sports Rep. (last visited Nov. 24, 2020), https://www.legalsportsreport.com/oregon/ [https://perma.cc/2N3L-EMZA] (suggesting that location in the state alone is sufficient to use the app).

97 See Matt Stout, With a Jab at Massachusetts, N.H. Ushers in Online Sports Betting, Bos. GLOBE (Dec. 30, 2019, 7:17 PM), https://www.bostonglo be.com/metro/2019/12/30/with-jab-massachusetts-ushers-online-sportsbetting/sjv4YKLbX5Rluz52mtnKxO/story.html (on file with the Columbia Business Law Review); Tim Callery, Mobile Sports Betting App Launches Monday in New Hampshire, WMUR (Dec. 30, 2019, 6:29 PM), https://www.wmur.com/article/mobile-sports-betting-new-hampshireupdate/30360070 [https://perma.cc/4SUT-2TAS]. 
from January 2010 through September 2019.98 I drew this data from the National Mortgage Database (NMDB), a "nationally representative, 5 percent sample of all outstanding, closed-end, first-lien, 1-4 family residential mortgages."99 Within this sample, I focus on the rate of mortgages by state that were delinquent from thirty to eightynine days, analyzing 5,967 observations dating back to January 2010.

Dependent variable selection is paramount to any regression analysis because regressions simply measure how independent variables influence the dependent variable. $100 \mathrm{I}$ focus on mortgage delinquency for four reasons. First, mortgages represent "the single largest market for consumer finance."101 Second, mortgage payments traditionally are due each month, representing an important financial decision-to pay or not to pay-that millions of consumers make at regular intervals. 102 Third, the NMDB's monthly data allow for robust empirical analysis of policy changes following Murphy that would be more difficult with data released at less frequent intervals. 103 Fourth, while many national databases update

98 "A mortgage is considered delinquent or late when a scheduled payment is not made on or before the due date." U.S. DEP'T OF HoUs. \& URB. DEV., supra note 21, at 8 tbl.Helpful Terms.

99 About the Data, supra note 23.

100 See Julian J. FARAWAY, Linear Models WITH R 7 (2009) (ebook) ("Regression analysis is used for explaining or modeling the relationship between a single variable $Y$, called the response, output or dependent variable; and one or more predictor, input, independent, or explanatory variables, $\left.X_{1}, \ldots, X_{p} . "\right)$.

101 Fed. Hous. Fin. Agency, supra note 24.

102 See U.S. DeP'T OF Hous. \& URB. DeV., supra note 21, at 2 (describing the usual payment schedule); Anna Bahney, Millions of Homeowners Are Now Delaying Their Mortgage Payments, CNN (Apr. 20, 2020, 6:54 PM), https://www.cnn.com/2020/04/20/success/mortgage-forbearancecoronavirus/index.html [https://perma.cc/P44Q-253J] (describing attempts by millions of mortgagors to delay payments).

103 See About the Data, supra note 23 ("Each [digital record] shows monthly delinquency rates going back to January 2008.”). 
with considerable lag, the NMDB updates quarterly, providing a fresh look at consumer credit health. 104

Independent variables should help explain the variation observed in the dependent variable. 105 This Note's first model employs a fifty-state dataset that indicates on a binary scale whether a state had legal sports betting in each month since January 2010. The second model uses a comprehensive panel dataset that reflects the degree of legalization in each state by incorporating the regulatory classifications proposed in Part II and summarized in Table 5.

Table 5106

\begin{tabular}{|c|l|l|}
\hline \multicolumn{3}{|l|}{ State Panel Data Classifications, September 2019} \\
\hline Class & Criteria & Membership \\
\hline \hline 0 & $\begin{array}{l}\text { No legal single-game sports } \\
\text { betting }\end{array}$ & $\begin{array}{l}\text { Thirty-seven states and } \\
\text { D.C. }\end{array}$ \\
\hline 1 & $\begin{array}{l}\text { Legal in-person sports betting, no } \\
\text { online option }\end{array}$ & $\begin{array}{l}\text { DE, MS, IN, NM, NY, } \\
\text { AR, OR }\end{array}$ \\
\hline 2 & $\begin{array}{l}\text { Legal in-person sports betting, } \\
\text { internet sports betting with } \\
\text { registration requirement }\end{array}$ & NV, RI, IA \\
\hline 3 & $\begin{array}{l}\text { Legal in-person and internet } \\
\text { sports betting }\end{array}$ & NJ, PA, WV \\
\hline
\end{tabular}

104 Compare Robert B. Avery et Al., Fed. Hous. Fin. Agency \& Bureau of Consumer Fin. Prot., National Mortgage Database TeChniCAL Documentation 8 (2020), https://www.fhfa.gov/PolicyPrograms Research/Programs/Documents/NMDB-Technical-Documentation20200310.pdf [https://perma.cc/D8NE-BUER] (mortgage data updated quarterly), with, e.g., Melonie Heron, Deaths: Leading Causes for 2017, NAT'L ViTAL STATS. REPS., June 24, 2019, at 2, https://www.cdc.gov/nchs/ data/nvsr/nvsr68/nvsr68_06-508.pdf [https://perma.cc/EP4U -CVHF] (releasing mortality data with a two-year lag).

105 See FARAWAY, supra note 100, at 7; cf. also Difference-in-Difference Estimation, Colum. UnIV. MaIlman Sch. OF Pub. Health, (last visited Jan. 17, 2020), https://www.mailman.columbia.edu/research/population-healthmethods/difference-difference-estimation [https://perma.cc/373A-QVAG] ("D[ifference-in-difference regression] is typically used to estimate the effect of a specific intervention or treatment[.]").

106 For these classifications, see supra Part II. 
The third model uses state-by-state betting data107 and analyzes the consumer credit impact of each additional dollar wagered on sports.

The final elements of the models are control variables: inputs uncorrelated with the treatments but substantially explaining changes in the dependent variable and thus helping to isolate the impact of legal sports betting. 108 I include four such controls. The first is the unemployment rate given in the Local Area Unemployment Statistics (LAUS) dataset released each month by the Bureau of Labor Statistics.109 The second is the gross domestic product (GDP), released quarterly by the Bureau of Economic Analysis in annualized form for each state. 110 Finally, I assign each month a season (e.g., winter) and each state a region (e.g., Southeast) in order to account for variation driven by regionality and seasonality. 111

\section{B. Methodology}

To estimate the connection between legal sports betting and mortgage delinquency rates within a state, I use the difference-in-differences (DiD) approach. This method is common in studies of regulatory interventions and public

107 For a compilation of these data, see infra Part VI app. A.

108 See ANGRIST \& PischKe, supra note 26, at 17-18.

109 See Concepts and Definitions, U.S. Bureau of LAB. Stats. (last updated June 19, 2020) https://www.bls.gov/cps/definitions.htm [https://perma.cc/HQR3-V58H] (explaining the calculation of the unemployment rate for the Current Population Survey). The LAUS program uses the same concept. See Overview, U.S. Bureau of LAB. STATS. (last updated Mar. 2020), https://www.bls.gov/lau/lauov.htm [https://perma.cc/ZvZ7-J6NV] ("The concepts and definitions underlying LAUS data come from the Current Population Survey[.]”).

110 See Press Release, Bureau of Econ. Analysis, Gross Domestic Product by State, Third Quarter 2019 (Jan. 10, 2020), https://www.bea.gov/system/files/2020-01/qgdpstate0120_2.pdf [https://perma.cc/RR66-8UQE] (summarizing the Bureau's GDP concept).

111 The seasonal classification is conventional. For the regional classification, see infra Part VI app. C. 
health programs. ${ }^{112}$ It helps show how populations that have experienced a policy change deviate from comparable populations that have not.113 One notable example of DiD comparing states is the groundbreaking minimum wage research conducted by David Card and Alan B. Krueger.114 After New Jersey raised its minimum wage in 1992, Card and Krueger used DiD to analyze New Jersey's divergence from Pennsylvania, which kept its minimum wage constant.115 They found that the higher minimum wage did not contribute to job losses, despite the predictions of traditional microeconomic models. 116

Similarly, I use the 37 states that have kept sports betting prohibitions in place as control populations to isolate the impact of legalization. The DiD method assumes that the control and treatment groups exhibited similar trends before the policy change took place.117 As seen in Figure 3, the preMurphy mortgage delinquency trends of treatment (legalizing) and control (non-legalizing) states conform to this assumption relatively well.

112 See Difference-in-Difference Estimation, supra note 105; ANGRIST \& PISCHKE, supra note 26, at 169.

113 See Difference-in-Difference Estimation, supra note 105; ANGRIST \& PISCHKE, supra note 26, at 169-74.

114 See generally David Card \& Alan B. Krueger, Minimum Wages and Employment: A Case Study of the Fast Food Industry in New Jersey and Pennsylvania, 84 Am. Econ. REV. 772 (1994). Professor Krueger died in 2019. I would like to recognize his great contributions to economic research. I and many others mourn his passing.

115 See id. at 778-79.

116 See id. at 792 .

117 See ANGRIsT \& PischKe, supra note 26, at 171-72 ("The key identifying assumption ... is that ... trends would be the same in both states in the absence of treatment."); Difference-in-Difference Estimation, supra note 105. 


\section{Figure 3}

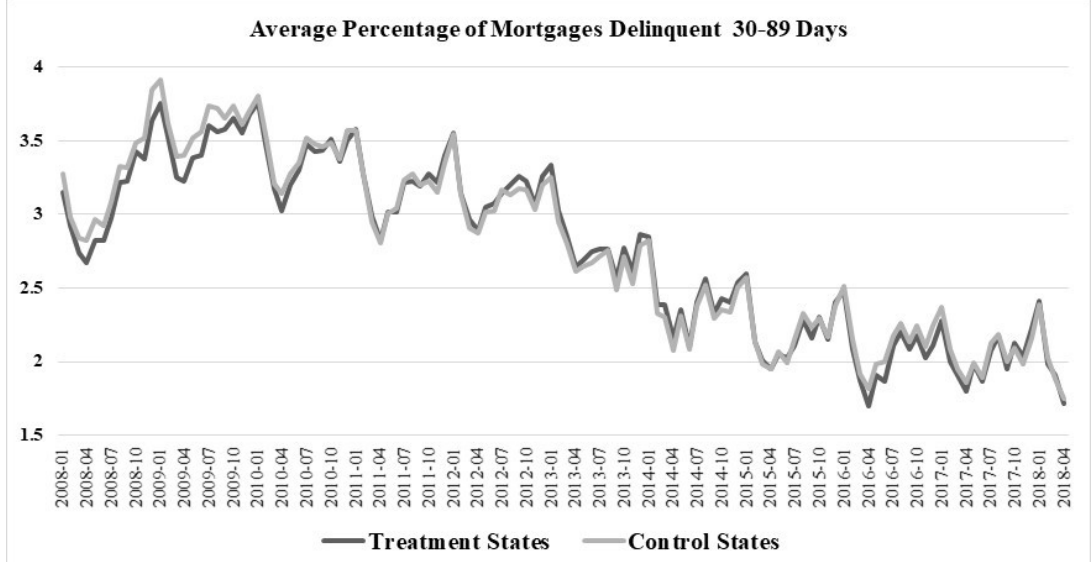

Turning to the mechanics of the study, I primarily implemented the DiD approach using traditional ordinary least squares linear regression. 118 Linear regression is a common predictive technique in the field of statistics. ${ }^{119}$ At bottom, it compares movements in one or more independent variables to the observed fluctuations in a dependent variable. 120 It then analyzes whether each independent variable had a relationship with the dependent variable not

118 I used Microsoft Excel's built-in regression tool, as well as Columbia Business School's proprietary Business Analytics Plug In. I also utilized the Real Statistics Resource Pack. Charles Zaiontz, Real Statistics Using Excel, REAL STATS., (last visited Nov. 24, 2020), http://www.real-statistics.com/ free-download/ [https://perma.cc/E26P-G7P3]. Additionally, I used generalized least squares regression to conduct robustness checks on each model.

119 David H. Kaye \& David A. Freedman, Statistical Models, in 1 MoD. SCI. Evidence $§ 5: 52$, Westlaw (David L. Faigman et al. eds., database updated Nov. 2019).

120 See id.; BARBARA Illowsky eT AL., INTRODUCtory Statistics 685-87 (2013) (ebook), https://d3bxy9euw4e147.cloudfront.net/oscms-prodcms/ media/documents/IntroductoryStatistics-OP_i6tAI7e.pdf [https://perma.cc/F9D9-784J]. 
caused by random chance and estimates the strength of that relationship (summarized by a coefficient " $\beta$ "). 121

A regression can be reduced to a simple equation that describes the independent and dependent variables and their relations. 122 This Note's empirical analysis takes the following general form, where $i$ indexes the state jurisdiction and $t$ indexes time 123 :

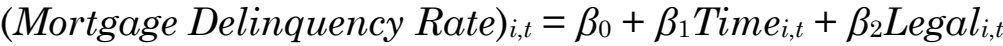

$$
\begin{aligned}
& +\beta_{3} \text { Time }_{i, t} \times \text { Legal }_{i, t}+\beta_{4} G D P_{i, t}+\beta_{5} \text { Unemployment }_{i, t}+ \\
& \beta_{6} \text { RegionFE }_{i}+\beta_{7} \text { SeasonalFE } E_{i, t}+\mathcal{E}_{i, t .} \text {. }
\end{aligned}
$$

In the above equation, the dependent variable is the percentage of mortgages that were between thirty and eightynine days delinquent in each month in each state. 124 Because time of year and location and influenced delinquency rates as seen in Figure 3, the equation includes "fixed effects" controls for regional variation $\left(\beta_{6}\right)$ and seasonal variation $\left(\beta_{7}\right) .^{125}$ Additionally, because of the relationship between macroeconomic health and mortgage performance,126 I included state gross domestic product $\left(\beta_{4}\right)$ and unemployment rate $\left(\beta_{5}\right)$ in the model as control variables. These four inputsregion, season, GDP, and unemployment-improve the

121 See Daniel L. Rubinfeld, Econometrics in the Courtroom, 85 CoLUM. L. REV. 1048, 1054, 1065-68 (1985).

122 See ILlOWSKY ET AL., supra note 120, at 688.

123 This equation mirrors the spreadsheet that contains inputs to the model. For the spreadsheet, see Clarida, supra note 24.

124 I selected these data as bellwethers for consumer credit health. See supra Section III.A. Observations come from the NMDB. See National Mortgage Database (NMDB) Aggregate Data, FED. Hous. Fin. AgEnCy (last updated June 29, 2020), https:/www.fhfa.gov/DataTools/Downloads/

Pages/National-Mortgage-Database-Aggregate-Data.aspx [https://perma.cc/42C8-S76U] (click "National Delinquency Rates in the United States").

125 For a discussion of fixed effects, see ANGRIST \& PISCHKE, supra note 26, at 221-27.

126 See John Y. Campbell \& Joao F. Cocco, 70 J. FIN. 1495, 1499 (2015) ("[T]he mortgage default rate and the equilibrium mortgage premium decrease with the expected growth rate of labor income."). 
model's explanatory power by accounting for variation in mortgage delinquency rates that is not explained by legal sports betting. 127

\section{Figure 4}

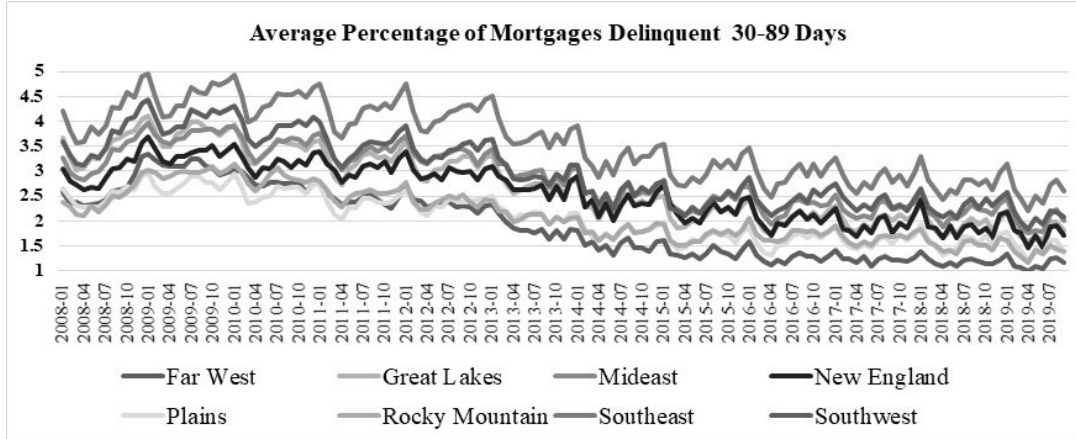

$\beta_{0}$ is the model's intercept. This figure represents the baseline average of the mortgage delinquency rate that the independent variables do not explain. ${ }^{128}$ Time $_{i, t}$ indicates, by taking a value of zero or one, whether a given observation of a state occurred before or after Murphy. This is critical, because it allows the model to measure-through the coefficient $\beta_{1}-$ how the situation in each state changed after the decision. 129 The next variable, Legal $l_{i, t}$, represents the sports betting regulations in each state in each month on a binary basis (Model One), on a degree of legalization basis (Model Two), or by indicating the total amount monthly amount wagered on sports (Model Three).

The crux of the DiD regression is $\beta_{3}$, the coefficient of the product of the timing variable (Time ${ }_{i, t}$ ) and the treatment variable $\left(\right.$ Legal $\left._{i, t}\right)$. This interaction term measures how states that legalized sports betting deviated in mortgage

127 See supra note 111 and accompanying text.

128 See ATA Airlines, Inc. v. Fed. Express Corp., 665 F.3d 882, 890 (7th Cir. 2011) (Posner, J.) (describing the function of the intercept in a regression model).

129 See id. (describing the function of a coefficient in a regression model). 
delinquency rates from both their pre-legalization trend and the trends of states that did not legalize. 130

\section{Results}

I investigate the connection between legal sports betting and consumer credit health from three vantage points. Model One examines whether the presence of sports betting in a state- represented by a one-zero binary for each state in each month-affects that state's mortgage delinquency rates. Model Two asks whether the degree of legalizationrepresented by regulatory classifications constructed in Part II-is significant. Model Three charts the relationship between each additional dollar wagered on sports and mortgage delinquency rates. Supporting technical material appears in the appendices. 131

The three models suggest causal-not just correlationalrelationships because the identification strategy capitalizes on a natural experiment: the staggered adoption of unique sports betting regulations. 132 While I could not control for all unobservable factors as one could in a randomized study, this Note's empirical design marks a helpful first step in evaluating the role of legalized sports betting in society and justifying some degree of caution among policymakers.

\section{The Presence of Legal Sports Betting}

Model One addresses a threshold question: does the presence of legal sports betting alone - with no consideration of the scope of legalization or the amount of money wagered-

130 See Difference-in-Difference Estimation, supra note 105.

131 See infra Part VI app. B (containing summary data as well as tests of linearity and normality).

132 See Craig et al., supra note 37, at 1832-33 (suggesting that welldesigned natural experiments, minimally defined as precluding "exposure to the event or intervention of interest . . manipulated by the researcher," may support causal inferences). But see ANGRIST \& PISCHKE, supra note 26, at 18-22 (endorsing causal inference from natural experiments but implicitly limiting the term to occurrences close to random in their mitigation of selection bias). 
contribute to a statistically significant change in mortgage delinquency rates, controlling for GDP, unemployment, regionality, and seasonality? This is a DiD regression of the following form, with the interaction term bolded 133 :

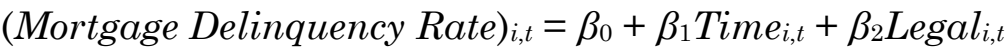

$+\beta_{3}$ Time $_{i, t} \times$ Legal $_{i, t}+\beta_{4} G D P_{i, t}+\beta_{5}$ Unemployment $_{i, t}+$ $\beta_{6}$ RegionFE $_{i}+\beta_{7}$ SeasonalFE $_{i, t}+\varepsilon_{i, t}$.

\section{Table 6}

\begin{tabular}{|c|c|c|c|}
\hline \multicolumn{4}{|c|}{$\begin{array}{c}\text { Model One: Does the Presence of Legal Sports Betting Impact } \\
\text { Mortgage Delinquency }\end{array}$} \\
\hline Overview & & & Significance Tests \\
\hline Observations & 5967 & & $p<.1 \quad *$ \\
\hline $\begin{array}{l}\text { Dependent } \\
\text { Variable }\end{array}$ & $\begin{array}{l}\text { Mortgage Delinquency } \\
\text { Rate, 30-89 Days }\end{array}$ & & $p<.05$ \\
\hline Methodology & $\mathrm{DiD}$ & & $p<.01 \quad * * *$ \\
\hline \multicolumn{4}{|c|}{ OLS, Traditional Standard Errors } \\
\hline \multicolumn{4}{|c|}{ Model Statistics } \\
\hline $\mathrm{R}^{2}$ & & & $73.57 \%$ \\
\hline Adjusted $\mathrm{R}^{2}$ & & & $73.51 \%$ \\
\hline F Statistic & & & 1104.6 \\
\hline Standard Error & & & 0.495 \\
\hline Variable & Coefficients & & Standard Error \\
\hline Intercept & 0.162 & $* * *$ & 0.035 \\
\hline Time & -0.072 & $* * *$ & 0.021 \\
\hline $\begin{array}{l}\text { Legal (Presence of } \\
\text { Legalization) }\end{array}$ & -0.03 & & 0.055 \\
\hline Time $*$ Legal & 0.304 & $* * *$ & $\mathbf{0 . 0 7 3}$ \\
\hline GDP & $-6.43 \mathrm{E}-08$ & $* * *$ & $1.60 \mathrm{E}-08$ \\
\hline Unemployment & 0.265 & $* * *$ & 0.003 \\
\hline Great Lakes & 0.851 & $* * *$ & 0.029 \\
\hline Mideast & 1.075 & $* * *$ & 0.028 \\
\hline New England & 1.016 & $* * *$ & 0.029 \\
\hline
\end{tabular}

133 For a discussion of the variables in the regression, see supra Section III.B. 


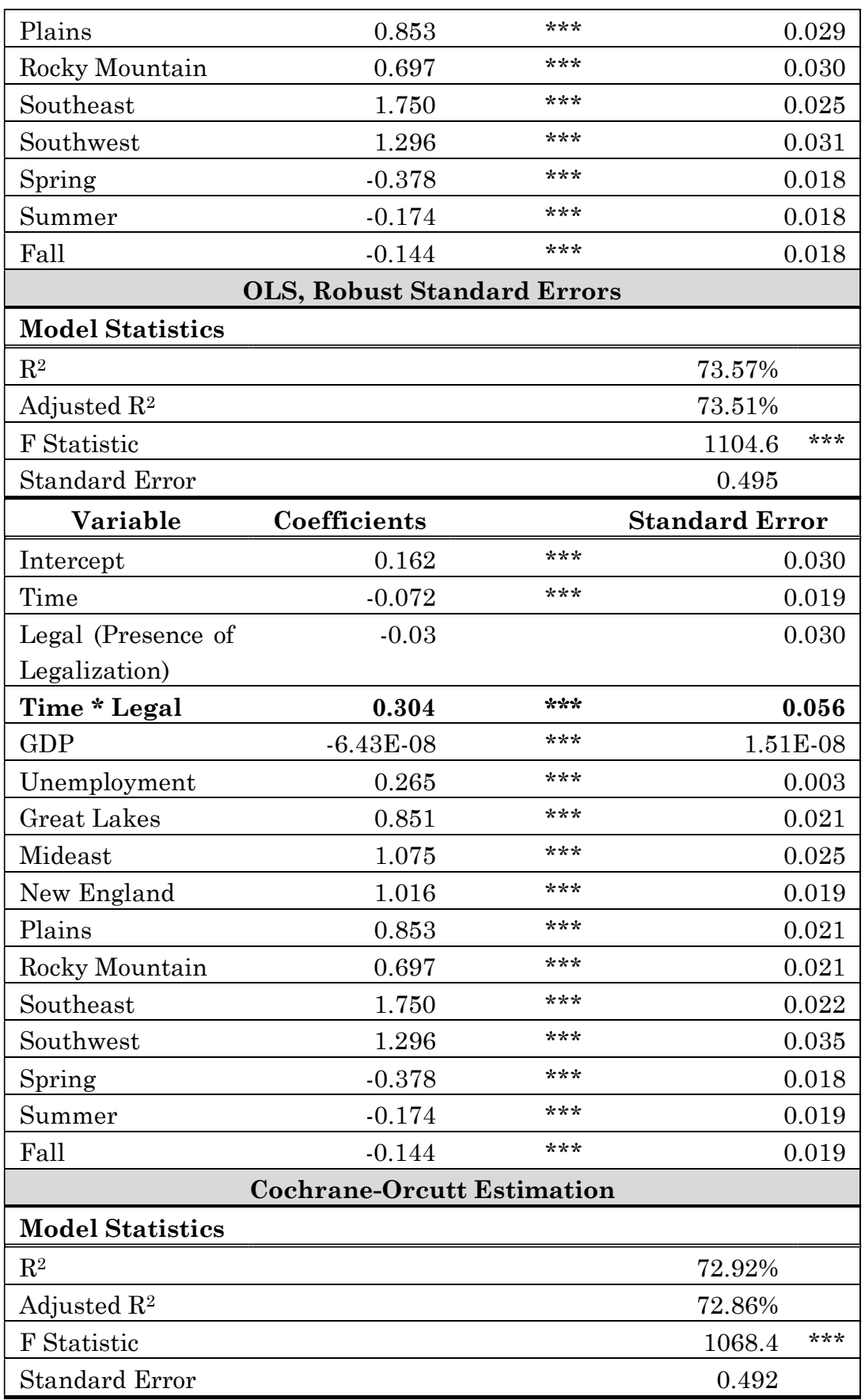




\begin{tabular}{|lrrrl|}
\hline \multicolumn{1}{|c}{ Variable } & Coefficients & & Standard Error & vif \\
\hline \hline Intercept & 0.264 & $* * *$ & 0.036 & 0.000 \\
\hline Time & -0.112 & $* * *$ & 0.024 & 1.326 \\
\hline $\begin{array}{l}\text { Legal (Presence of } \\
\text { Legalization) }\end{array}$ & -0.08 & & 0.054 & 2.575 \\
\hline Time ${ }^{*}$ Legal & & & & \\
\hline GDP & $\mathbf{0 . 3 6 7}$ & $* * *$ & $\mathbf{0 . 0 7 2}$ & $\mathbf{2 . 4 5 8}$ \\
\hline Unemployment & $-5.00 \mathrm{E}-08$ & $* * *$ & $1.58 \mathrm{E}-08$ & 1.245 \\
\hline Great Lakes & 0.251 & $* * *$ & 0.004 & 1.513 \\
\hline Mideast & 0.812 & $* * *$ & 0.029 & 1.804 \\
\hline New England & 1.125 & $* * *$ & 0.027 & 1.904 \\
\hline Plains & 0.975 & $* * *$ & 0.028 & 2.180 \\
\hline Rocky Mountain & 0.763 & $* * *$ & 0.029 & 2.470 \\
\hline Southeast & 0.640 & $* * *$ & 0.030 & 2.016 \\
\hline Southwest & 1.769 & $* * *$ & 0.024 & 2.601 \\
\hline Spring & 1.289 & $* * *$ & 0.029 & 1.596 \\
\hline Summer & -0.376 & $* * *$ & 0.021 & 1.514 \\
\hline Fall & -0.173 & $* * *$ & 0.021 & 1.529 \\
\hline & -0.145 & $* * *$ & 0.021 & 1.498 \\
\hline
\end{tabular}

I implemented this design through three regressions. The first uses traditional standard errors, a common starting point for regression analyses. 134 The second uses Eicker-HuberWhite "robust" standard errors to address heteroskedasticity in the data. 135 The third uses the Cochrane-Orcutt estimation procedure to correct for serial autocorrelation common in time series studies.136 These alternate approaches serve as

134 See Rubinfeld, supra note 121, at 1066-67; see also ILLOWSKY, supra note 120 , at 687 (describing the calculation of these errors).

135 See Halbert White, A Heteroskedasticity-Consistent Covariance Matrix Estimator and a Direct Test for Heteroskedasticity, 48 ECONOMETRICA 817, 820-21 (1980) (presenting the estimator underlying this procedure).

136 D. Cochrane \& G. H. Orcutt, Application of Least Squares Regression to Relationships Containing Auto-Correlated Error Terms, $44 \mathrm{~J}$. Am. STAT. Ass'N 32, 53-55 (1949) (proposing the procedure); David E. A. Giles \& Murray Beattie, Autocorrelation Pre-Test Estimation in Models with a Lagged Dependent Variable, in Specification Analysis in the Linear Model 99, 99 (Maxwell L. King \& David E. A. Giles eds., 1987) (reaffirming the applicability of the Cochrane-Orcutt procedure). 
robustness checks and support the estimations of the initial model. 137

In the primary model, the "Time*Legal" coefficient, estimated at 0.304 percent, indicates the impact of sports betting legalization.138 This coefficient is statistically significant at the one-percent level, meaning that there is only a remote chance that randomness explains the result.139 Moreover, the coefficient appears substantively significant: the treatment effect of legalization- 0.304 percent-explains more than a quarter of the observed sample standard deviation in mortgage delinquency rates (0.96)140 and is slightly greater than the estimated impact of a one-percent change in unemployment. Additionally, the model's RSquared figure indicates that the independent variables explain 73.57 percent of the observed variability. 141

The relationships between the control and dependent variables further support the model's internal validity. Rising GDP correlates positively with consumption 142 and should correlate negatively with mortgage delinquency rates. Thus, these rates should fall as GDP rises, and Model One estimates that they do. Rising unemployment should have the opposite effect, placing downward pressure on consumption. Mortgage delinquency rates should therefore rise as unemployment rises, 143 and Model One reflects this.

Nevertheless, this model provides a rather blunt view of the policy choice at hand. Legalizing sports betting is not a binary choice: states may craft diverse and detailed regulatory

137 A further discussion follows infra Section III.D.

138 Note that the estimate is $0.304 / 1$, not $0.304 / 100$, because the NMDB represents five percent as "5.0" rather than ".05."

139 See Daniel L. Rubinfeld, Practical and Statistical SignificanceWhat Is the Appropriate Level of Statistical Significance?, in 1 MoD. ScI. EVIDENCE, supra note 119, § 6:13.

140 See infra Part VI app. B tbl.Summary Statistics.

141 See ILlOWsKY, supra note 120, at 691 (discussing the interpretation of R-Squared values).

142 See Paula-Elena Diacon \& Liviu-George Maha, 23 Procedia Econ. \& FIN. 1535, 1536, 1537 fig.1 (2015).

143 See Campbell \& Cocco, supra note 126, at 1499. 
schemes. While Class Three states, like New Jersey, have permissive approaches to sports betting with many in-person and online options, 144 Class One states like Delaware only offer sports betting at casinos and retailers. ${ }^{145}$ A shortcoming of Model One is that it treats these states identically.

\section{The Degree of Legalization}

Model Two retains the DiD approach but replaces the Legal $_{i, t}$ binary term with a score between zero and three for each state in each month from January 2010 through September 2019. These scores, presented again in Table 7, reflect the classificatory scheme in Part II.

Table 7146

\begin{tabular}{|l|l|l|}
\hline \multicolumn{3}{|l|}{ State Panel Data Classifications, September 2019 } \\
\hline Class & Criteria & Membership \\
\hline \hline 0 & $\begin{array}{l}\text { No legal single-game sports } \\
\text { betting }\end{array}$ & $\begin{array}{l}\text { Thirty-seven states and } \\
\text { D.C. }\end{array}$ \\
\hline 1 & $\begin{array}{l}\text { Legal in-person sports betting, no } \\
\text { online option }\end{array}$ & $\begin{array}{l}\text { DE, MS, IN, NM, NY, } \\
\text { AR, OR }\end{array}$ \\
\hline 2 & $\begin{array}{l}\text { Legal in-person sports betting, } \\
\text { internet sports betting with } \\
\text { registration requirement }\end{array}$ & NV, RI, IA \\
\hline 3 & $\begin{array}{l}\text { Legal in-person and internet } \\
\text { sports betting }\end{array}$ & NJ, PA, WV \\
\hline
\end{tabular}

The regression equation, with the interaction term bolded, is as follows:

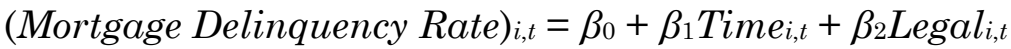
$+\beta_{3}$ Time $_{i, t} \times$ RegClassification $_{i, t}+\beta_{4} G D P_{i, t}+$

$\beta_{5}$ Unemployment $_{i, t}+\beta_{6}$ RegionFE $_{i}+\beta_{7}$ SeasonalFE $_{i, t}+\varepsilon_{i, t}$.

144 See supra notes 80-84 and accompanying text.

145 See supra notes 50-56 and accompanying text.

146 This table also appears supra Section III.B tbl.5. 
Table 8

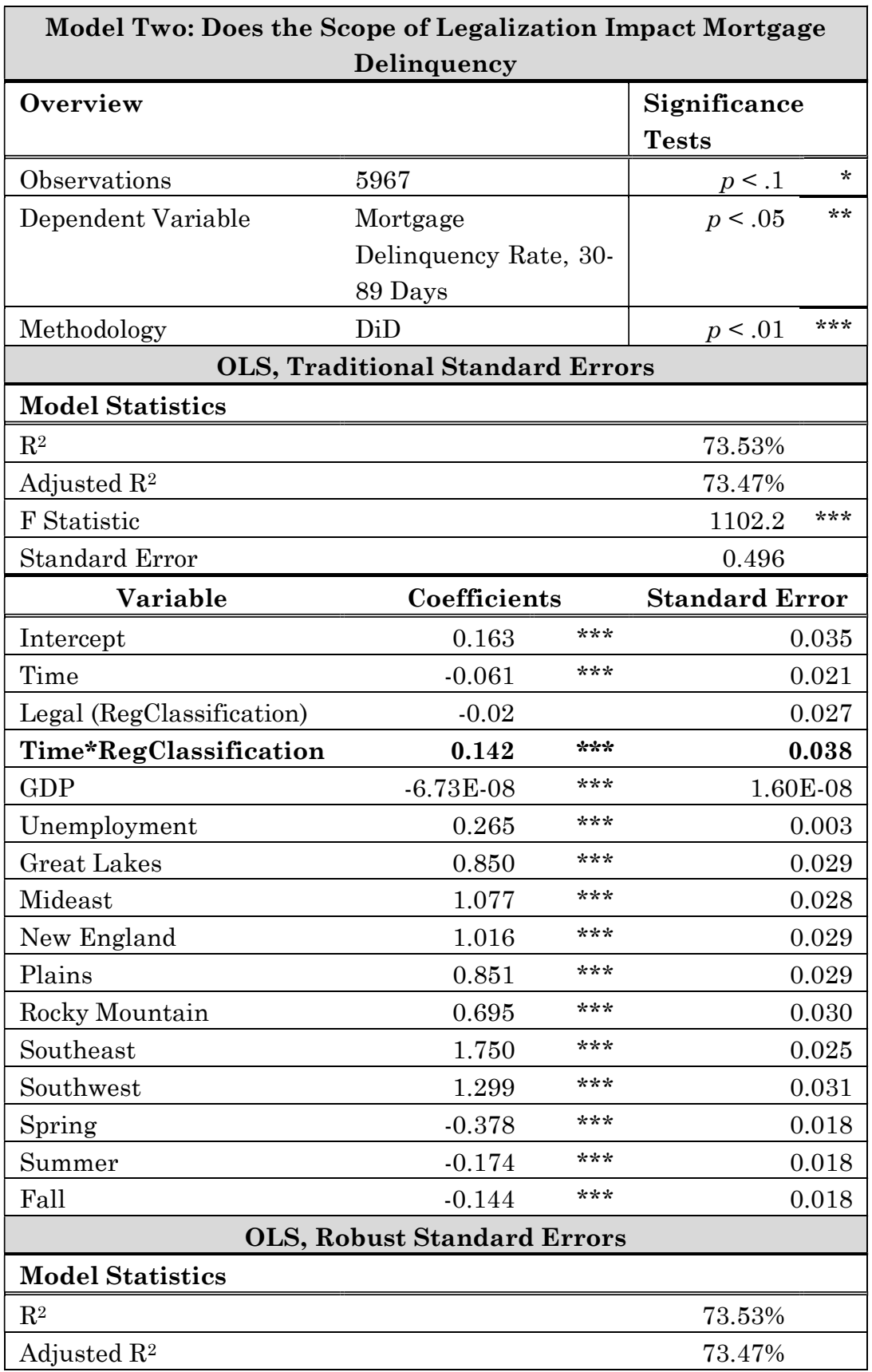




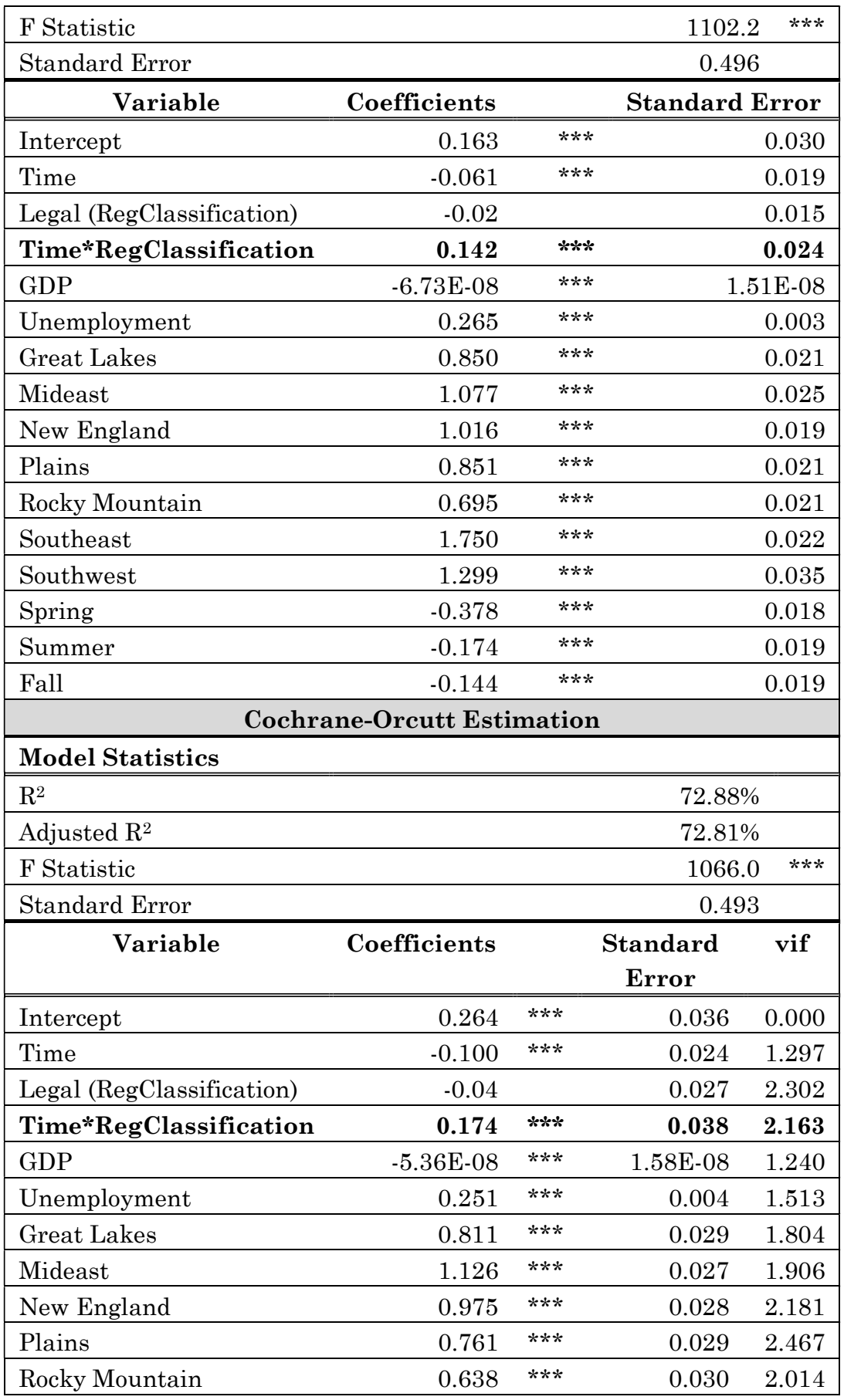




\begin{tabular}{|lllll|}
\hline Southeast & 1.769 & $* * *$ & 0.024 & 2.602 \\
\hline Southwest & 1.292 & $* * *$ & 0.029 & 1.598 \\
\hline Spring & -0.376 & $* * *$ & 0.021 & 1.514 \\
\hline Summer & -0.173 & $* * *$ & 0.021 & 1.529 \\
\hline Fall & -0.144 & $* * *$ & 0.021 & 1.498 \\
\hline
\end{tabular}

As with Model One, I evaluate Model Two using traditional standard errors, Eicker-Huber-White robust standard errors, and the Cochrane-Orcutt method.147 The three approaches each find a statistically significant positive association between more permissive legal sports betting and mortgage delinquency. The estimated effect of "increasing" a state's regulatory class - 0.142 percent in the primary model 148 - is the "Time*RegClassification" coefficient, which is statistically significant at the one-percent level.149 This estimate is also substantively significant: a one-class change accounts for nearly fifteen percent of the observed standard deviation in delinquency rates (0.96). 150 Compared to Model One, the RSquared figure falls slightly from 73.57151 percent to 73.53 percent of delinquency variability explained, while the GDP and unemployment controls have the expected relationship with the outcome variable. 152

While Model Two's treatment coefficient is smaller than Model One's, it is important to note that the corresponding variable takes values from zero to three, not just the values zero and one. Thus, Class Three states like New Jersey would expect a larger impact from sports gambling-three multiplied by 0.142 , or 0.426 - than Class One states. The model therefore estimates higher delinquency rates in states that have legalized more aggressively, holding the control variables equal. Model Two is thus fairly consistent with

147 See supra notes 134-37 and accompanying text.

148 For a clarification of this interpretation, see supra note 138.

149 For a brief discussion of statistical significance, see supra note 139 and accompanying text.

150 For the standard deviation and other summary data, see infra Part VI app. B tbl.Summary Statistics.

151 See supra Section III.C.1.

152 See supra notes 142-43 and accompanying text. 
Model One but provides more insight into the impact of the scope of legalization offered in each state.

\section{The Amount Wagered}

The regulatory classifications used in Model Two approximate the level of legalization in each state that permits sports betting. A potentially more precise way to analyze a state's degree of legalization is to examine the amount of money bet on sports in each state, which is generally referred to as the handle. Unfortunately, a major challenge with this method is that, at the time of this study, four states-New Mexico, New York, Arkansas, and Oregoneither had released no data or incomplete data. 153 However, these are states where there has been relatively little legal sports betting. New Mexico offers sports betting only at a few tribal casinos, 154 and New York and Arkansas also have few betting options. 155 Oregon's tribal sports betting did not begin until August 27, 2019.156 Therefore, while this model has important data limitations, it still may provide a more nuanced look than the research classifications used in Models One and Two. The regression equation is as follows:

$$
\begin{gathered}
\left(\text { Mortgage Delinquency Rate }_{i, t}=\beta_{0}+\beta_{1} \text { Handle }_{i, t}+\right. \\
\beta_{2} \text { GDP }_{i, t}+\beta_{3} \text { Unemployment }_{i, t}+\beta_{4} \text { RegionFE }_{i}+ \\
\beta_{5} \text { SeasonalFE }_{i, t}+\varepsilon_{i, t} .
\end{gathered}
$$

153 See infra Part VI app. A (collecting the available data in the study period).

154 See Legal Sports Betting in New Mexico, US BeTting ReP. (last updated Dec. 13, 2020), https://usbettingreport.com/sports-betting/newmexico/ [https://perma.cc/QU95-2WYE].

155 See supra notes 50-52.

156 See Chinook Winds Casino Opens First Sportsbook Lounge in Oregon, supra note 52. 
Table 9

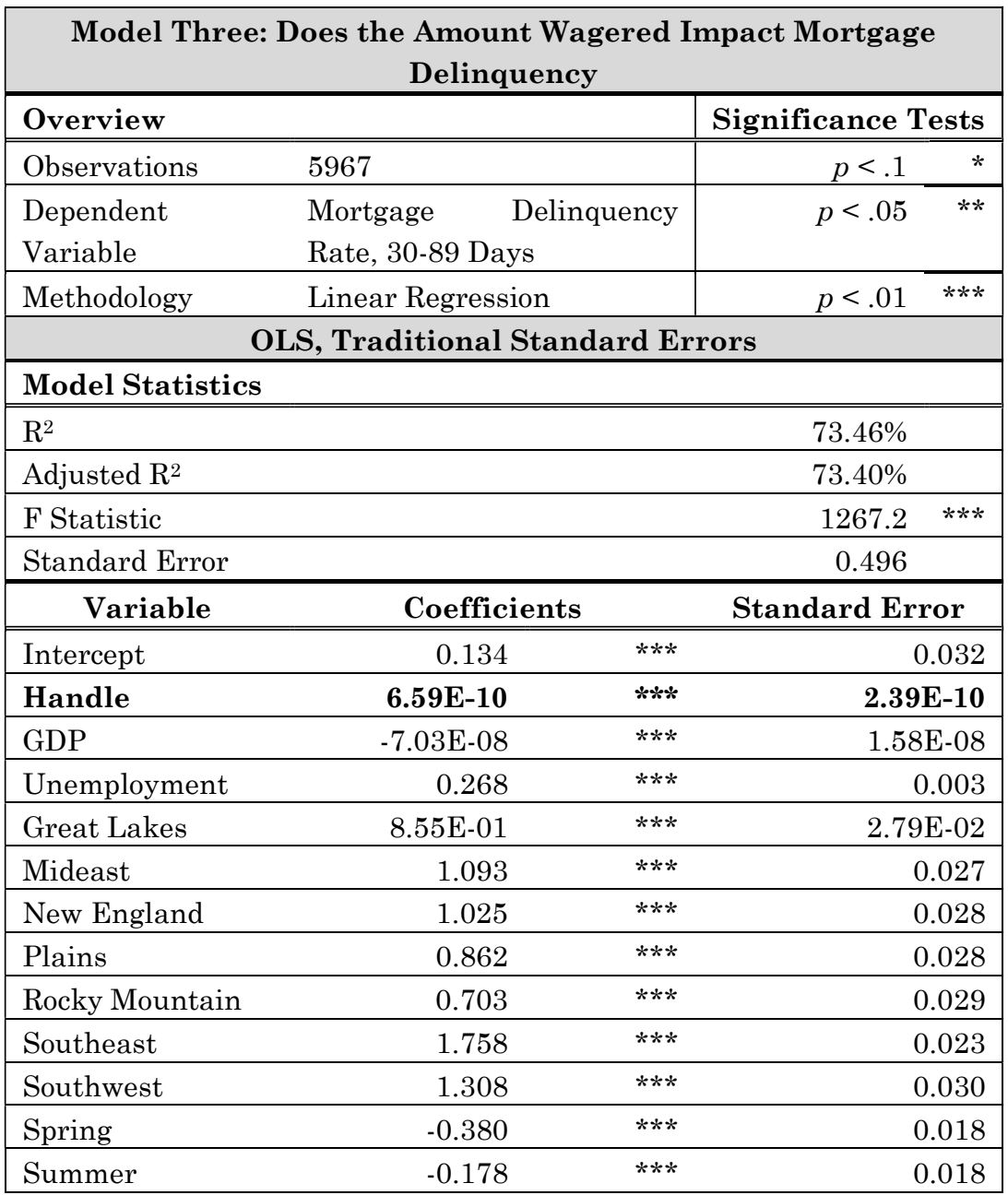




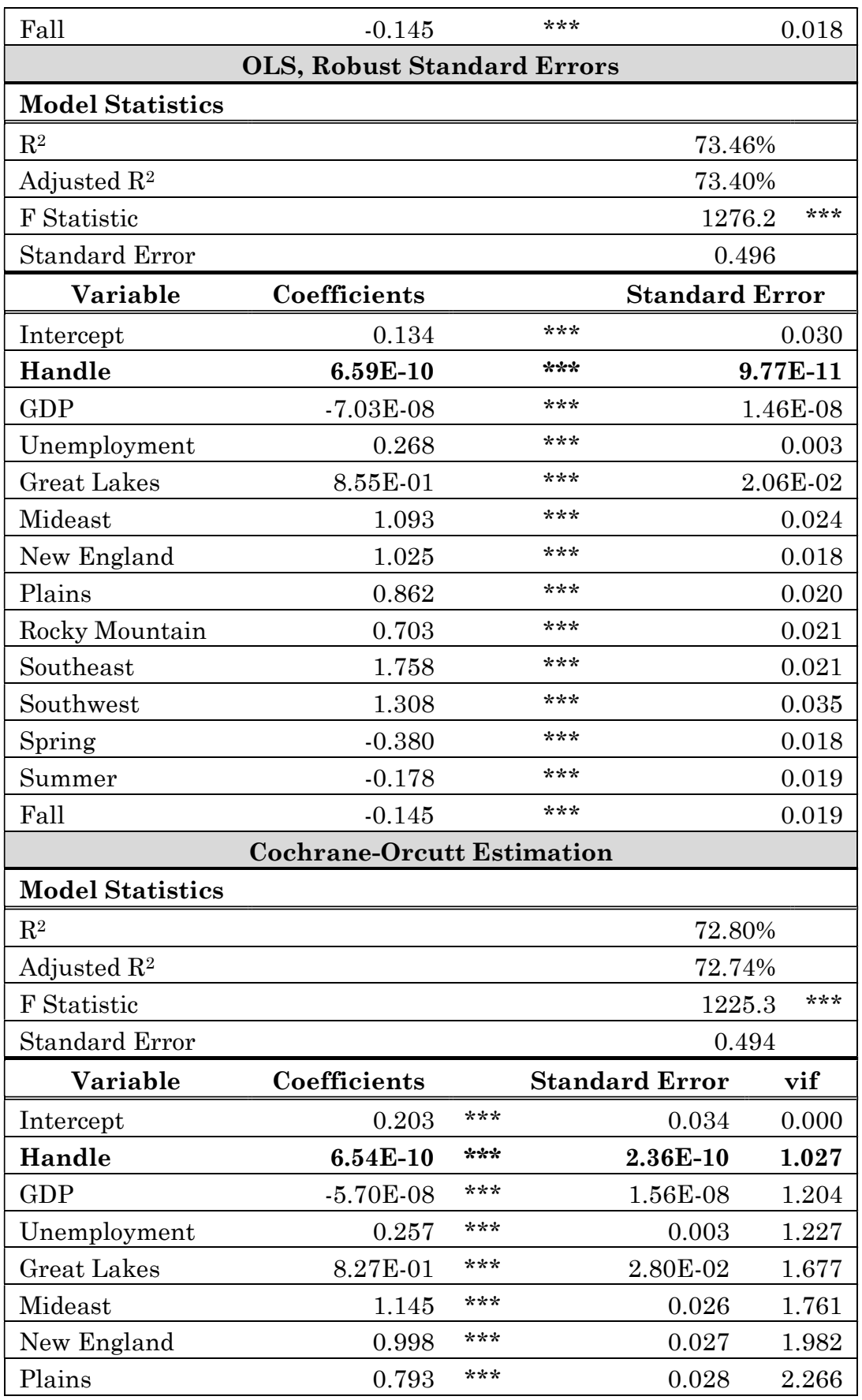




\begin{tabular}{|lclll|}
\hline Rocky Mountain & 0.661 & $* * *$ & 0.029 & 1.882 \\
\hline Southeast & 1.783 & $* * *$ & 0.023 & 2.345 \\
\hline Southwest & 1.309 & $* * *$ & 0.029 & 1.523 \\
\hline Spring & -0.379 & $* * *$ & 0.021 & 1.513 \\
\hline Summer & -0.180 & $* * *$ & 0.021 & 1.516 \\
\hline Fall & -0.147 & $* * *$ & 0.021 & 1.496 \\
\hline
\end{tabular}

Model Three's output is largely consistent with Models One and Two. 157 It indicates that each additional dollar bet on sports has a small, upward, and statistically significant relationship with mortgage delinquency rates. The coefficient for the "Handle" variable reflects this and is significant at the one-percent level.158 As in Model One and Model Two, the GDP and unemployment variables in Model Three have the expected relationships with mortgage delinquency. 159

\section{Objections and Limitations}

While regressions alone do not provide definitive evidence of causal links, I submit that the time-series methodology and associated results above do report a form of correlation suggestive of causality. 160 Nevertheless, my research is only a first step toward analyzing a relatively recent policy problem, and I acknowledge its limitations. First, the models presented above each display evidence of heteroskedasticity and autocorrelation. Second, primarily due to data availability, I used a relatively small number of control variables. Finally, Model Two relied on the regulatory classifications I described in Part II, and these state-by-state classifications involved research judgments that may be revisited.

157 For the results of these models, see supra Sections III.C.1-.2.

158 Models 1 and 2 also were significant at the one-percent level. However, the statistics academy generally accepts significance at the five percent level. See Rubinfeld, supra note 142, § 6:13.

159 See supra notes 142-43 and accompanying text.

160 See supra note 132 and accompanying text. 


\section{Technical Issues}

Heteroskedasticity is relatively common in economic studies. 161 It occurs when the variances of the errors in a regression model are not identical.162 This is a violation of standard regression assumptions that often occurs when prediction errors correlate with model variables.163 This Note's three models exhibit heteroskedasticity: plots of residuals against fitted values for each model show trademark "cone" shapes, with each model becoming less reliable as predicted values rise. 164

\section{Figure 5165}

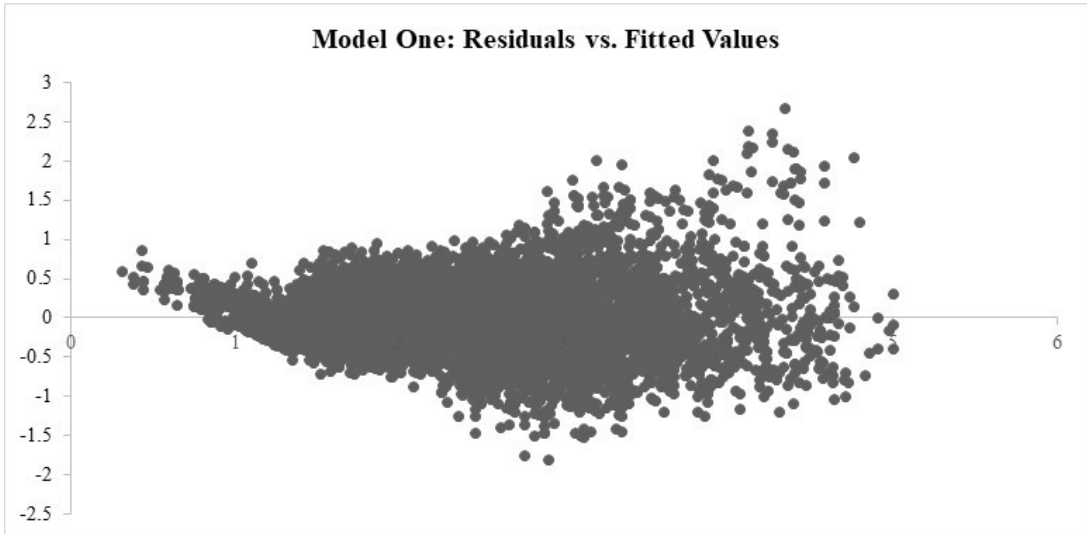

161 See Ingrid Van Keilegom \& Lan Wang, Semiparametric Modeling and Estimation of Heteroscedasticity in Regression Analysis of CrossSectional Data, 4 ElEC. J. STAT. 133, 133 (2010), ("The problem of heteroscedasticity, which traditionally means nonconstant variance function, frequently arises in regression analysis of economic data.").

162 RichaRd Williams, HeterosKeDASTICITY 1 (2020), https://www3 .nd.edu/ rwilliam/stats2/125.pdf [https://perma.cc/W9KL-2WML].

163 See id.

164 See FARAWAY, supra note 100, at 59 fig.4.1 (displaying a similar plot).

165 For the full set of plots, see infra figs.B.4, B.5 \& B. 6 . 
The presence of heteroskedasticity does not mean that a model's coefficients are incorrect.166 Rather, heteroskedasticity indicates that the significance testswhich report the probability of the coefficients being caused by random chance-may be inaccurate. 167 To correct this issue, I ran a second iteration of each model using the heteroskedasticity-consistent covariance estimator approach developed by White, Huber, and Eicker.168 This technique produces "robust" standard errors not influenced by the unfulfilled regression assumptions and therefore supports more reliable significance tests. 169 These tests confirmed my original results. 170

Serial correlation also is a common issue in time series analyses, and it is present in this Note's models.171 I confirmed this by performing the Durbin-Watson test, which reported statistically significant serial correlation in the error

166 ROBERT L. KAUFMan, Heteroskedasticity IN REgREssion: DETECTION AND CORRELATION 3 (2013) ("If there is heteroskedasticity, the good news is that using [ordinary least squares regression] to estimate [the model] provides unbiased estimates of the coefficients.").

167 See id. at 3; White, supra note 135, at 817 ("It is well known that the presence of heteroskedasticity in the disturbances of an otherwise properly specified linear model leads to consistent but inefficient parameter estimates and inconsistent covariance matrix estimates. As a result, faulty inferences will be drawn when testing statistical hypotheses in the presence of heteroskedasticity.").

168 See supra note 135 and accompanying text. But see Gary King \& Margaret E. Roberts, How Robust Standard Errors Expose Methodological Problems They Do Not Fix, and What To Do About It, 23 Pol. ANALYsis 159, 159-60 (2015) (criticizing widespread improper use of robust standard errors). Calculated robust standard errors appear supra Sections III.C.1 tbl.6, III.C.2 tbl.8 \& III.C.3 tbl.9.

169 See Williams, supra note 162 , at 6-7.

170 Note that the coefficient of each variable stayed the same. This is because calculating standard error in a different way is unrelated to the value of the coefficient. See id. at 7. In fact, the heteroskedasticityconsistent errors generally were lower than traditional standard errors. Professors Angrist and Pischke suggest "taking the maximum of the conventional standard error and a robust standard error as your best measure of precision.” ANGRIST \& PISCHKE, supra note 26, at 230.

171 See Difference-in-Difference Estimation, supra note 105 (advising corrections for autocorrelation in time series DiD regressions). 
terms of each model.172 This correlation may impact the reliability of significance tests. 173 While robust standard errors may mitigate this issue, I also used the CochraneOrcutt procedure to address it. 174 The correction did modify the coefficients of the treatment variables, but the changes were minor, and the results retained statistical significance at the one-percent level. 175

\section{Variable Selection}

I turn next to my selection of variables. At the outset of this study, I considered a number of options for the dependent variable, including a variety of data related to consumer credit health. I selected mortgage delinquency in part because monthly readings are available with a short lag, making this data fresher than other options. 176 This freshness is critical because the policy changes at issue in this Note are less than three years old. As time passes, however, a wider variety of datasets will become suitable for analysis. Future researchers may find, for example, that other datasets are more responsive to the policy changes at issue than mortgage delinquency rates.

My choice of independent variables also presents an opportunity for extension. From the outset, I chose to focus on simple, macroeconomic relationships-those involving GDP

172 See generally J. Durbin \& G. S. Watson, Testing for Serial Correlation in Least Squares Regression. I, 37 BIOMETRIKA 409 (1950) (explaining the theory behind the test); J. Durbin \& G. S. Watson, Testing for Serial Correlation in Least Squares Regression. II, 38 BIOMETRIKA 159, 160-166 (1951) (explaining the test's calculation).

173 See ANGRIST \& PISCHKE, supra note 26, at 236.

174 See supra note 136 and accompanying text; see also Difference-inDifferences Estimation, supra note 105 (suggesting that robust standard errors may mitigate issues with autocorrelation).

175 The results appear supra Sections III.C.1 tbl.6, III.C.2 tbl.8 \& III.C.3 tbl.9.

176 See supra note 104 and accompanying text. For potential data that I rejected due to frequency and other issues, see Center for Microeconomic Data, FED. RsRv. BANK OF N.Y. (last visited Nov. 25, 2020), https:/www.new yorkfed.org/microeconomics/databank.html [https://perma.cc/9Z5C-AS52]. 
and unemployment-that are familiar to most readers and would allow for relatively straightforward statistical analysis. I also limited independent variables to ensure that the variance inflation factors remained within acceptable ranges. 177

Nevertheless, more comprehensive controls may be beneficial. For example, future researchers may attempt to control for the availability of traditional gambling in each state under the assumption that sports betting activity may be greater or smaller in states where significant alternatives exist. Relatedly, researchers may attempt to control for spillover effects, such as New Yorkers' access to New Jersey internet sports betting upon crossing state borders. 178 To the extent possible, researchers may also control for the relative availability of illegal sports betting in each state, especially if the state offers no other sports betting or if these illegal options attract players with better user experiences or more favorable wagering odds. 179

Another potential set of controls would try to capture how income distribution impacts both who decides to bet on sports and how that choice affects mortgage delinquency, especially because gambling in general appears to be regressive. 180 Finally, as with many policy impact studies, it remains

177 See Maria Lucia Passador \& Federico Riganti, Shareholders'Rights in Agency Conflicts, 42 DEL. J. CORP. L. 569, 608-09 (noting that high variance inflation factors suggest multicollinearity-a problem in regression analysis). This study reports variance inflation factors supra Sections III.C.1 tbl.6, III.C.2 tbl.8 \& III.C.3 tbl.9.

178 See Campanile, supra note 48 (describing the spillover phenomenon).

179 See Puneet Pal Sing, How Does Illegal Sports Betting Work and What Are the Fears?, BBC (Feb. 19, 2013), https://www.bbc.com/news/busine ss-21501858 [https://perma.cc/4PN8-CPV5] ("There are various reasons behind [illegal betting]. . . . In some countries, the most basic reason is a ban on sports betting. Meanwhile, in others some of the illegal betting syndicates offer better odds for a sporting event, making the payout in case of a winning bet, more attractive.").

180 See Mary O. Borg, Paul M. Mason \& Stephen L. Shapiro, The Incidence of Taxes on Casino Gambling: Exploiting the Tired and Poor, 50 Am. J. Econ. \& Socio. 323, 323, 326-27 (1991). 
possible that state legislatures have addressed sports betting in a way that reflects unobserved qualities shared by their citizens. 181 While the DiD methodology aims to account for unobserved pre-treatment trends, I still acknowledge that the models in this Note do not by themselves support a definitive causal link. 182

\section{Regulatory Classification}

A third shortcoming of my empirical design is the regulatory panel data elaborated in Part II and used in Model Two. The coding of this data demanded some exercise of judgment. The weightiest judgment call was the decision to score Nevada-the epicenter of gambling in the United States-as a Class Two state. I did this because Nevada's regulatory scheme requires potential bettors to register their online wagering accounts in person, supporting casino employment, but also posing an obstacle to betting that other states-most notably New Jersey-have removed.183 Another example of research judgment is the coding of Delaware and Oregon as "zeroes" before May 2018, even though each of those states legalized sports lottery games during some period beforehand.184 I did this because neither allowed single-game sports wagering, unlike Nevada. 185 Finally, I acknowledge that my coding procedure lumped states together only on the basis of their sports betting regulations without taking into account other factors that may be significant, like the availability of non-sports gambling. Nevertheless, this regulatory panel data was an input only in Model Two, which returned estimates that were consistent with Models One and Three, lending some confidence to the classifications.

181 Cf. Difference-in-Difference Estimation, supra note 105 (discussing the selection problem).

182 See id. (discussing the conditions necessary to permit reliable inference from DiD studies).

183 See supra Sections II.C-.D.

184 See S. REP. No. 102-248, at 10 (1991).

185 See id. (comparing the two states' sports betting systems with Nevada's). 


\section{Implications for Policymakers and Researchers}

In Part III, I used DiD regression to analyze the relationship between legal sports gambling and consumer credit health, for which I selected mortgage delinquency rates as a proxy. I constructed three models, each of which suggested a small, positive, and statistically significant relationship between legal sports betting and mortgage delinquency rates. I noted that while my findings do not justify a definitive causal link, the time series design and associated results do report a form of correlation suggestive of causality. 186 I then highlighted various opportunities to improve the empirical design. I now propose a preliminary application of these findings to pending policy decisions.

In August of 2019, Connecticut continued to debate legal sports betting. 187 State legislative analysts had estimated in 2018 that a "limited availability" legalization would result in $\$ 2.2$ billion of annual handle in the state, or an average of approximately $\$ 180$ million bet legally on sports each month. 188 The models I showcase above can help analyze the impact of this potential policy choice. The estimates returned by Models One and Two predict that a small, upward, and statistically significant pressure on mortgage delinquency rates would accompany legalization. 189 Model Three's estimates sharpen this insight by indicating the impact of each dollar legally wagered on sports. Thus, Model Three allows for a comparison between Connecticut's eventual decision not to legalize (yet) and a counterfactual situation in

186 See supra Section III.D.2.

187 See Christopher Keating, Gov. Ned Lamont Excluded from Drafting of Gambling Legislation that Could Bring Connecticut \$200M in New Revenue, HARTFORD COURANT (Aug. 4, 2019, 6:00 AM), https://www.courant .com/politics/hc-pol-lamont-excluded-casino-talks-20190804-

hpreuf2osrallasbtugxrkbj64-story.html (on file with the Columbia Business Law Review).

188 Chen \& Miles, supra note 25, at 30.

189 See supra text accompanying notes 138-40, 148-50. 
which the state saw $\$ 180$ million in legal sports bets in October 2019.190

To analyze the no-legalization status quo, Model Three ingests Connecticut's actual GDP and unemployment figures for October 2019. We can then safely assume that Connecticut residents legally wagered $\$ 0$ on sports in the state, because sports betting is illegal in the status quo. From these inputs, Model Three estimates that Connecticut's rate of delinquent mortgages would have declined slightly, from 2.1 percent to 1.96 percent. The prediction column records the product of the Model Three coefficient and the corresponding assumed input.

Table 10

\begin{tabular}{|l|r|r|r|}
\hline \multicolumn{4}{|c|}{ Scenario One: Connecticut, Oct. 2019, No Legalization } \\
\hline Variable & Coefficient & Assumption & Prediction \\
\hline \hline Intercept & 0.13 & 1 & 0.13 \\
Handle & 0.00 & 0 & 0.00 \\
GDP & 0.00 & 288,985 & -0.02 \\
Unemployment & 0.27 & 3.6 & 0.97 \\
Region: New England & 1.02 & 1 & 1.02 \\
Season: Fall & -0.15 & 1 & -0.15 \\
\hline Predicted Mortgage Delinquency & & $\mathbf{1 . 9 6}$ \\
\hline
\end{tabular}

In the counterfactual analysis, Model Three again incorporates Connecticut's actual GDP and unemployment figures for October 2019. We then assume that Connecticut approved sports betting in September 2019 and launched it on October 1, 2019, seeing $\$ 180$ million in legal bets that month.191 The model estimates that, in this scenario, Connecticut's rate of delinquent mortgages at the end of October reaches 2.08 percent, versus 1.96 percent in the status quo analysis.

190 Models One and Two would allow for a similar comparison, conceptually, but neither is able to incorporate estimates of the amount of money wagered per month.

191 Chen \& Miles, supra note 25, at 30. 
Table 11

\begin{tabular}{|l|r|r|r|}
\hline \multicolumn{3}{|c|}{ Scenario One: Connecticut, Oct. 2019, “Limited Availability" } \\
Legalization \\
\hline Variable & Coefficient & Assumption & Prediction \\
\hline \hline Intercept & 0.13 & 1 & 0.13 \\
Handle & 0.00 & $180,000,000$ & 0.12 \\
GDP & 0.00 & 288,985 & -0.02 \\
Unemployment & 0.27 & 3.6 & 0.97 \\
Region: New England & 1.02 & 1 & 1.02 \\
Season: Fall & -0.15 & 1 & -0.15 \\
\hline Predicted Mortgage Delinquency & & $\mathbf{2 . 0 8}$ \\
Change from No Legalization & $\mathbf{5 . 7 1 \%}$ \\
\hline
\end{tabular}

Of course, this counterfactual analysis depends on its assumptions and may be refined. For example, Connecticut's 2018 analysis projected that legalization would create new jobs. 192 According to Model Three, if the state had experienced a modest decline in unemployment from 3.6 percent to 3.3 percent in addition to seeing $\$ 180$ million in legal sports bets, nearly all of the mortgage delinquency effects of the change would have disappeared.

\section{Table 12}

\begin{tabular}{|c|c|c|c|}
\hline \multicolumn{4}{|c|}{$\begin{array}{c}\text { Scenario Three: Connecticut, Oct. 2019, "Limited Availability" } \\
\text { Legalization and Decline in Unemployment }\end{array}$} \\
\hline Variable & Coefficient & Assumption & Prediction \\
\hline Intercept & 0.134 & 1 & 0.13 \\
\hline Handle & $6.594 \mathrm{E}-10$ & $180,000,000$ & 0.12 \\
\hline GDP & $-7.028 \mathrm{E}-08$ & 288,985 & -0.02 \\
\hline Unemployment & 0.268 & 3.3 & 0.88 \\
\hline Region: New England & 1.025 & 1 & 1.02 \\
\hline Season: Fall & -0.145 & 1 & -0.15 \\
\hline \multicolumn{3}{|c|}{ Predicted Mortgage Delinquency } & 2.00 \\
\hline \multicolumn{3}{|c|}{ Change from No Legalization } & $1.95 \%$ \\
\hline
\end{tabular}

192 Chen \& Miles, supra note 25, at 9 . 
This case study suggests an important policy insight: the negative consumer credit consequences of legal sports betting may be offset by gains in employment. This proposition may support the regulatory strategies of states which have decided to route legal sports betting through existing casinos and racetracks. States have accomplished this in a number of ways. Class One states center all sports betting at existing brick-and-mortar facilities since they prohibit internet sports wagers. 193 While this may encourage new employment, these states have also seen relatively small amounts of legal wagering compared to states that allow internet sports betting. 194 Class Two states employ a compromise: all new internet sports bettors must register at existing casinos or racetracks, so the regulations encourage patronization of these facilities while tapping into the lucrative online market. 195 Even Class Three states generally require internet operators to affiliate with existing casinos, although it is unclear if this arrangement encourages employment.196 This Note's results suggest that protecting and even incentivizing casino employment, as Class One and Class Two states do, may be a viable way to undercut the negative consumer credit impacts of legal sports betting.

As Justice Alito observed in Murphy, "Congress can regulate sports gambling directly, but if it elects not to do so, each State is free to act on its own." 197 So far, states have done all of the work, crafting their own regulatory schemes. If the federal government decides to get involved, it will have to make the same policy decisions this Note has analyzed at the state level. Notably, the recent Hatch-Schumer Act, a regulatory proposal which failed to advance in Congress, sought to allow internet sports betting without an in-person registration requirement.198 This Note's models indicate that

193 See supra Section II.B.

194 See infra Part VI app. A.

195 See supra Section II.C.

196 See supra text accompanying notes 83-85.

197 Murphy v. Nat'l Collegiate Athletic Ass'n, 138 S. Ct. 1461, 1484-85 (2018).

198 See Hatch-Schumer Act, S. 3793, 115th Cong. § 103 (2018). 
such a requirement may be beneficial if it allows enough casino employees to share in the benefits of legal sports betting and therefore mitigates the consumer credit impact of legalization.

Finally, I stress that I have made a preliminary attempt at addressing an urgent question. If nothing else, my empirical methods indicate that there is enough data available to begin rigorous quantitative study of the policy choices associated with legal sports betting. The research opportunity is ripe and will improve over time as more regulatory approaches emerge and more data become available.

\section{CONCLUSION}

As more states throw their hats into the ring of legalized sports betting, it is incumbent on policymakers to develop a more complete understanding of the impacts of legalization. This is not an easy mandate. Isolating the effects of the available policy choices requires robust data and creative methodologies. This Note makes the first attempt at an empirical analysis of these policy options and their potential impacts on consumer credit health. It finds a small, upward, and statistically significant relationship between mortgage delinquency rates and both legal sports betting and unemployment. This result suggests that the optimal legal sports betting framework incentivizes employment in order to mitigate the negative consumer health consequences of increased gambling. It is also consistent with the observation that betting on sports is not a good investment. At best, it is a leisure activity that is a drain on our available resources. Policymakers should consider it accordingly. 


\section{APPENDICES}

\section{Appendix A: State Betting Totals and Panel Data}

This data is released periodically by state authorities and compiled by Legal Sports Report, an industry website. 199

\section{Table A.1}

\begin{tabular}{|c|c|c|c|}
\hline State & Month & Handle & Revenue \\
\hline New Jersey & Jun-18 & $\$ 16,409,619$ & $\$ 3,458,668$ \\
\hline New Jersey & Jul-18 & $\$ 40,682,237$ & $\$ 3,845,880$ \\
\hline New Jersey & Aug-18 & $\$ 95,634,048$ & $\$ 9,198,272$ \\
\hline New Jersey & Sep-18 & $\$ 183,948,404$ & $\$ 23,775,366$ \\
\hline New Jersey & Oct-18 & $\$ 260,711,301$ & $\$ 11,686,119$ \\
\hline New Jersey & Nov-18 & $\$ 330,748,563$ & $\$ 21,243,865$ \\
\hline New Jersey & Dec-18 & $\$ 319,173,548$ & $\$ 20,814,222$ \\
\hline New Jersey & Jan-19 & $\$ 385,279,662$ & $\$ 18,777,582$ \\
\hline New Jersey & Feb-19 & $\$ 320,368,087$ & $\$ 12,732,740$ \\
\hline New Jersey & Mar-19 & $\$ 372,451,342$ & $\$ 31,669,387$ \\
\hline New Jersey & Apr-19 & $\$ 313,719,562$ & $\$ 21,215,747$ \\
\hline New Jersey & May-19 & $\$ 318,940,677$ & $\$ 15,536,384$ \\
\hline New Jersey & Jun-19 & $\$ 273,222,975$ & $\$ 9,701,925$ \\
\hline New Jersey & Jul-19 & $\$ 273,222,975$ & $\$ 9,701,925$ \\
\hline New Jersey & Aug-19 & $\$ 293,594,862$ & $\$ 25,210,342$ \\
\hline New Jersey & Sep-19 & $\$ 445,563,503$ & $\$ 37,883,375$ \\
\hline New Jersey & Oct-19 & $\$ 487,924,504$ & $\$ 46,393,537$ \\
\hline New Jersey & Nov-19 & $\$ 562,675,543$ & $\$ 32,895,546$ \\
\hline New Jersey & Dec-19 & $\$ 557,786,161$ & $\$ 29,424,884$ \\
\hline New Jersey & Jan-20 & $\$ 540,113,452$ & $\$ 53,561,626$ \\
\hline New Jersey & Feb-20 & $\$ 494,813,807$ & $\$ 17,000,928$ \\
\hline New Jersey & Mar-20 & $\$ 181,908,529$ & $\$ 13,181,101$ \\
\hline New Jersey & Apr-20 & $\$ 54,593,092$ & $\$ 2,634,050$ \\
\hline New Jersey & May-20 & $\$ 117,821,281$ & $\$ 9,912,062$ \\
\hline New Jersey & Jun-20 & $\$ 165,014,553$ & $\$ 12,639,282$ \\
\hline New Jersey & Jul-20 & $\$ 315,118,805$ & $\$ 29,551,987$ \\
\hline
\end{tabular}

199 US Sports Betting Revenue and Handle, supra note 14. 


\begin{tabular}{|c|c|c|c|c|}
\hline State & Month & Hold & Taxes & $\begin{array}{c}\text { Tax } \\
\text { Rate }\end{array}$ \\
\hline New Jersey & Jun-18 & $21.10 \%$ & $\$ 337,077$ & $9.75 \%$ \\
\hline New Jersey & Jul-18 & $9.50 \%$ & $\$ 377,015$ & $9.80 \%$ \\
\hline New Jersey & Aug-18 & $9.60 \%$ & $\$ 1,038,073$ & $11.29 \%$ \\
\hline New Jersey & Sep-18 & $12.90 \%$ & $\$ 2,883,517$ & $12.13 \%$ \\
\hline New Jersey & Oct-18 & $4.50 \%$ & $\$ 1536,282$ & $13.15 \%$ \\
\hline New Jersey & Nov-18 & $6.40 \%$ & $\$ 2,730,521$ & $12.85 \%$ \\
\hline New Jersey & Dec-18 & $6.50 \%$ & $\$ 2,695,290$ & $12.95 \%$ \\
\hline New Jersey & Jan-19 & $4.90 \%$ & $\$ 2,532,619$ & $13.49 \%$ \\
\hline New Jersey & Feb-19 & $4.00 \%$ & $\$ 1,817,553$ & $14.27 \%$ \\
\hline New Jersey & Mar-19 & $8.50 \%$ & $\$ 4,180,051$ & $13.20 \%$ \\
\hline New Jersey & Apr-19 & $6.80 \%$ & $\$ 2,817,206$ & $13.28 \%$ \\
\hline New Jersey & May-19 & $4.90 \%$ & $\$ 2,135,704$ & $13.75 \%$ \\
\hline New Jersey & Jun-19 & $3.60 \%$ & $\$ 1,258,541$ & $12.97 \%$ \\
\hline New Jersey & Jul-19 & $7.10 \%$ & $\$ 2,367,745$ & $13.24 \%$ \\
\hline New Jersey & Aug-19 & $8.60 \%$ & $\$ 3,327,589$ & $13.20 \%$ \\
\hline New Jersey & Sep-19 & $8.50 \%$ & $\$ 5,017,875$ & $13.25 \%$ \\
\hline New Jersey & Oct-19 & $9.50 \%$ & $\$ 5,662,148$ & $12.20 \%$ \\
\hline New Jersey & Nov-19 & $5.90 \%$ & $\$ 4,460,461$ & $13.56 \%$ \\
\hline New Jersey & Dec-19 & $5.30 \%$ & $\$ 4,016,635$ & $13.65 \%$ \\
\hline New Jersey & Jan-20 & $9.90 \%$ & $\$ 7,328,175$ & $13.68 \%$ \\
\hline New Jersey & Feb-20 & $3.40 \%$ & $\$ 2,377,923$ & $13.99 \%$ \\
\hline New Jersey & Mar-20 & $7.20 \%$ & $\$ 1,732,276$ & $13.14 \%$ \\
\hline New Jersey & Apr-20 & $4.80 \%$ & $\$ 356,726$ & $13.54 \%$ \\
\hline New Jersey & May-20 & $8.40 \%$ & $\$ 1,303,244$ & $13.15 \%$ \\
\hline New Jersey & Jun-20 & $7.70 \%$ & $\$ 1,652,950$ & $13.08 \%$ \\
\hline New Jersey & Jul-20 & $9.40 \%$ & $\$ 3,671,891$ & $12.43 \%$ \\
\hline
\end{tabular}

\section{Table A.2}

\begin{tabular}{|c|r|r|r|}
\hline \multicolumn{1}{|c}{ State } & \multicolumn{1}{c}{ Month } & \multicolumn{1}{c|}{ Handle } & \multicolumn{1}{c|}{ Revenue } \\
\hline Pennsylvania & Nov-18 & $\$ 1,414,587$ & $\$ 508,997$ \\
\hline Pennsylvania & Dec-18 & $\$ 16,173$ & $\$ 2,007,592$ \\
\hline Pennsylvania & Jan-19 & $\$ 32,011,839$ & $\$ 2,607,215$ \\
\hline Pennsylvania & Feb-19 & $\$ 31,500,742$ & $\$ 1,946,817$ \\
\hline Pennsylvania & Mar-19 & $\$ 44,527,575$ & $\$ 5,519,340$ \\
\hline Pennsylvania & Apr-19 & $\$ 36,769,145$ & $\$ 4,221,482$ \\
\hline
\end{tabular}




\begin{tabular}{|c|c|c|c|c|}
\hline Pennsylvania & May-19 & $\$ 35,934,215$ & & $\$ 2,861,852$ \\
\hline Pennsylvania & Jun-19 & $\$ 46,334,244$ & & $\$ 3,126,380$ \\
\hline Pennsylvania & Jul-19 & $\$ 59,331,959$ & & $\$ 5,079,633$ \\
\hline Pennsylvania & Aug-19 & $\$ 109,038,051$ & & $\$ 9,887,738$ \\
\hline Pennsylvania & Sep-19 & $\$ 194,504,622$ & & $\$ 19,334,816$ \\
\hline Pennsylvania & Oct-19 & $\$ 241,186,066$ & & $\$ 19,116,77$ \\
\hline Pennsylvania & Nov-19 & $\$ 316,468,264$ & & $\$ 20,570,772$ \\
\hline Pennsylvania & Dec-19 & $\$ 342,560,389$ & & $\$ 17,459,091$ \\
\hline Pennsylvania & Jan-20 & $\$ 348,381,708$ & & $\$ 31,580,803$ \\
\hline Pennsylvania & Feb-20 & $\$ 329,765,782$ & & $\$ 11,432,097$ \\
\hline Pennsylvania & Mar-20 & $\$ 131,330,059$ & & $\$ 8,606,120$ \\
\hline Pennsylvania & Apr-20 & $\$ 46,015,988$ & & $\$ 3,202,680$ \\
\hline Pennsylvania & May-20 & $\$ 77,510,033$ & & $\$ 5,918,697$ \\
\hline Pennsylvania & Jun-20 & $\$ 89,002,562$ & & $\$ 7,959,790$ \\
\hline Pennsylvania & Jul-20 & $\$ 164,782,229$ & & $\$ 13,651,865$ \\
\hline State & Month & Hold & Taxes & Tax Rate \\
\hline Pennsylvania & Nov-18 & $36.00 \%$ & $\$ 183,239$ & $36.00 \%$ \\
\hline Pennsylvania & Dec-18 & $12.40 \%$ & $\$ 722,733$ & $36.00 \%$ \\
\hline Pennsylvania & Jan-19 & $8.10 \%$ & $\$ 938,597$ & $36.00 \%$ \\
\hline Pennsylvania & Feb-19 & $6.20 \%$ & $\$ 700,854$ & $36.00 \%$ \\
\hline Pennsylvania & Mar-19 & $12.40 \%$ & $\$ 1,986,962$ & $36.00 \%$ \\
\hline Pennsylvania & Apr-19 & $11.50 \%$ & $\$ 1,519,734$ & $36.00 \%$ \\
\hline Pennsylvania & May-19 & $8.00 \%$ & $\$ 1,030,267$ & $36.00 \%$ \\
\hline Pennsylvania & Jun-19 & $6.80 \%$ & $\$ 740,455$ & $23.68 \%$ \\
\hline Pennsylvania & Jul-19 & $8.60 \%$ & $\$ 1,026,769$ & $20.21 \%$ \\
\hline Pennsylvania & Aug-19 & $9.10 \%$ & $\$ 2,201,406$ & $22.26 \%$ \\
\hline Pennsylvania & Sep-19 & $9.90 \%$ & $\$ 5,359,994$ & $27.72 \%$ \\
\hline Pennsylvania & Oct-19 & $7.90 \%$ & $\$ 5,381,370$ & $28.15 \%$ \\
\hline Pennsylvania & Nov-19 & $6.50 \%$ & $\$ 5,299,447$ & $25.76 \%$ \\
\hline Pennsylvania & Dec-19 & $5.10 \%$ & $\$ 4,094,813$ & $23.45 \%$ \\
\hline Pennsylvania & Jan-20 & $9.10 \%$ & $\$ 8,222,829$ & $26.04 \%$ \\
\hline Pennsylvania & Feb-20 & $3.50 \%$ & $\$ 1,700,911$ & $14.87 \%$ \\
\hline Pennsylvania & Mar-20 & $6.60 \%$ & $\$ 2,480,132$ & $28.82 \%$ \\
\hline Pennsylvania & Apr-20 & $7.00 \%$ & $\$ 1,038,050$ & $32.41 \%$ \\
\hline Pennsylvania & May-20 & $7.60 \%$ & $\$ 1,738,436$ & $29.37 \%$ \\
\hline Pennsylvania & Jun-20 & $8.90 \%$ & $\$ 2,397,657$ & $30.12 \%$ \\
\hline Pennsylvania & Jul-20 & $8.30 \%$ & $\$ 2,933,093$ & $21.48 \%$ \\
\hline
\end{tabular}




\section{Table A.3}

\begin{tabular}{|c|c|c|c|c|}
\hline State & Month & Handle & \multicolumn{2}{|c|}{ Revenue } \\
\hline Delaware & Jun-18 & $\$ 7,003,725$ & & $\$ 875,216$ \\
\hline Delaware & Jul-18 & $\$ 8,214,765$ & & $\$ 461,226$ \\
\hline Delaware & Aug-18 & $\$ 8,018,354$ & & $\$ 822,737$ \\
\hline Delaware & Sep-18 & $\$ 23,257,965$ & & $\$ 5,971,961$ \\
\hline Delaware & Oct-18 & $\$ 21,231,427$ & & $\$ 1,640,593$ \\
\hline Delaware & Nov-18 & $\$ 24,206,090$ & & $\$ 1,608,337$ \\
\hline Delaware & Dec-18 & $\$ 23,419,539$ & & $\$ 4,272,221$ \\
\hline Delaware & Jan-19 & $\$ 14,130,069$ & & $\$ 2,094,840$ \\
\hline Delaware & Feb-19 & $\$ 8,709,205$ & & $(\$ 475,771)$ \\
\hline Delaware & Mar-19 & $\$ 10,483,128$ & & $\$ 1,643,043$ \\
\hline Delaware & Apr-19 & $\$ 6,088,183$ & & $\$ 614,839$ \\
\hline Delaware & May-19 & $\$ 5,920,766$ & & $\$ 405,295$ \\
\hline Delaware & Jun-19 & $\$ 6,325,464$ & & $\$ 466,018$ \\
\hline Delaware & Jul-19 & $\$ 3,920,974$ & & $\$ 507,199$ \\
\hline Delaware & Aug-19 & $\$ 4,745,747$ & & $\$ 493,106$ \\
\hline Delaware & Sep-19 & $\$ 18,781,406$ & & $\$ 4,425,640$ \\
\hline Delaware & Oct-19 & $\$ 16,066,023$ & & $\$ 3,388,776$ \\
\hline Delaware & Nov-19 & $\$ 16,850,854$ & & $\$ 3,014,648$ \\
\hline Delaware & Dec-19 & $\$ 20,466,561$ & & $\$ 2,972,118$ \\
\hline Delaware & Jan-20 & $\$ 11,187,011$ & & $\$ 1,995,980$ \\
\hline Delaware & Feb-20 & $\$ 7,279,650$ & & $(\$ 303,120)$ \\
\hline Delaware & Mar-20 & $\$ 3,877,068$ & & $\$ 570,442$ \\
\hline Delaware & Jul-20 & $\$ 209,282$ & & $\$ 12,114$ \\
\hline State & Month & Hold & Taxes & Tax Rate \\
\hline Delaware & Jun-18 & $12.50 \%$ & $\$ 437,609$ & $50.00 \%$ \\
\hline Delaware & Jul-18 & $5.60 \%$ & $\$ 230,614$ & $50.00 \%$ \\
\hline Delaware & Aug-18 & $10.30 \%$ & $\$ 457,984$ & $55.67 \%$ \\
\hline Delaware & Sep-18 & $25.70 \%$ & $\$ 4,118,974$ & $68.97 \%$ \\
\hline Delaware & Oct-18 & $7.70 \%$ & $\$ 1,299,481$ & $79.21 \%$ \\
\hline Delaware & Nov-18 & $6.60 \%$ & $\$ 998,477$ & $62.08 \%$ \\
\hline Delaware & Dec-18 & $18.20 \%$ & $\$ 2,989,387$ & $69.97 \%$ \\
\hline Delaware & Jan-19 & $14.80 \%$ & $\$ 1,311,863$ & $62.62 \%$ \\
\hline Delaware & Feb-19 & $-5.50 \%$ & $(\$ 438,047)$ & $92.07 \%$ \\
\hline Delaware & Mar-19 & $15.70 \%$ & $\$ 821,072$ & $49.97 \%$ \\
\hline Delaware & Apr-19 & $10.10 \%$ & $\$ 307,046$ & $49.94 \%$ \\
\hline
\end{tabular}




\begin{tabular}{|l|r|r|r|r|}
\hline Delaware & May-19 & $6.80 \%$ & $\$ 202,247$ & $49.90 \%$ \\
\hline Delaware & Jun-19 & $7.40 \%$ & $\$ 232,733$ & $49.94 \%$ \\
\hline Delaware & Jul-19 & $12.90 \%$ & $\$ 253,516$ & $49.98 \%$ \\
\hline Delaware & Aug-19 & $10.40 \%$ & $\$ 241,770$ & $49.03 \%$ \\
\hline Delaware & Sep-19 & $23.60 \%$ & $\$ 3,123,828$ & $70.58 \%$ \\
\hline Delaware & Oct-19 & $21.10 \%$ & $\$ 2,358,625$ & $69.60 \%$ \\
\hline Delaware & Nov-19 & $17.90 \%$ & $\$ 2,167,507$ & $71.90 \%$ \\
\hline Delaware & Dec-19 & $14.50 \%$ & $\$ 2,032,440$ & $68.38 \%$ \\
\hline Delaware & Jan-20 & $17.80 \%$ & $\$ 1,190,481$ & $59.64 \%$ \\
\hline Delaware & Feb-20 & $-4.20 \%$ & $(\$ 337,668)$ & $111.40 \%$ \\
\hline Delaware & Mar-20 & $14.70 \%$ & $\$ 284,802$ & $49.93 \%$ \\
\hline Delaware & Jul-20 & $5.80 \%$ & $\$ 6,058$ & $50.01 \%$ \\
\hline
\end{tabular}

\section{Table A.4}

\begin{tabular}{|c|c|c|c|}
\hline State & Month & Handle & Revenue \\
\hline Mississippi & Aug-18 & $\$ 6,270,128$ & $\$ 645,057$ \\
\hline Mississippi & Sep-18 & $\$ 31,770,270$ & $\$ 5,503,793$ \\
\hline Mississippi & Oct-18 & $\$ 32,837,334$ & $\$ 1,178,343$ \\
\hline Mississippi & Nov-18 & $\$ 44,499,883$ & $\$ 1,674,250$ \\
\hline Mississippi & Dec-18 & $\$ 41,762,048$ & $\$ 6,174,224$ \\
\hline Mississippi & Jan-19 & $\$ 35,190,774$ & $\$ 2,793,238$ \\
\hline Mississippi & Feb-19 & $\$ 25,148,135$ & $\$ 2,756,439$ \\
\hline Mississippi & Mar-19 & $\$ 32,421,264$ & $\$ 4,898,726$ \\
\hline Mississippi & Apr-19 & $\$ 19,188,763$ & $\$ 2,057,834$ \\
\hline Mississippi & May-19 & $\$ 17,438,288$ & $\$ 1,191,967$ \\
\hline Mississippi & Jun-19 & $\$ 15,190,666$ & $\$ 1,625,113$ \\
\hline Mississippi & Jul-19 & $\$ 13,383,383$ & $\$ 1,053,776$ \\
\hline Mississippi & Aug-19 & $\$ 19,876,370$ & $\$ 2,884,348$ \\
\hline Mississippi & Sep-19 & $\$ 37,870,989$ & $\$ 5,631,583$ \\
\hline Mississippi & Oct-19 & $\$ 48,019,481$ & $\$ 12,295,357$ \\
\hline Mississippi & Nov-19 & $\$ 56,369,036$ & $\$ 3,784,919$ \\
\hline Mississippi & Dec-19 & $\$ 49,076,433$ & $\$ 3,478,919$ \\
\hline Mississippi & Jan-20 & $\$ 45,190,371$ & $\$ 4,637,967$ \\
\hline Mississippi & Feb-20 & $\$ 34,462,821$ & $\$ 2,105,780$ \\
\hline Mississippi & Mar-20 & $\$ 10,749,403$ & $\$ 648,647$ \\
\hline Mississippi & Apr-20 & N/A & N/A \\
\hline Mississippi & May-20 & $\$ 236,503$ & $\$ 87,697$ \\
\hline
\end{tabular}




\begin{tabular}{|c|c|c|c|c|}
\hline Mississippi & Jun-20 & $\$ 1,575,859$ & & $(\$ 62,231)$ \\
\hline Mississippi & Jul-20 & $\$ 7,916,665$ & & $\$ 1,335,763$ \\
\hline State & Month & Hold & Taxes & Tax Rate \\
\hline Mississippi & Aug-18 & $10.30 \%$ & $\$ 77,407$ & $12.00 \%$ \\
\hline Mississippi & Sep-18 & $17.30 \%$ & $\$ 660,455$ & $12.00 \%$ \\
\hline Mississippi & Oct-18 & $3.60 \%$ & $\$ 141,401$ & $12.00 \%$ \\
\hline Mississippi & Nov-18 & $3.80 \%$ & $\$ 200,910$ & $12.00 \%$ \\
\hline Mississippi & Dec-18 & $14.80 \%$ & $\$ 740,907$ & $12.00 \%$ \\
\hline Mississippi & Jan-19 & $7.90 \%$ & $\$ 335,189$ & $12.00 \%$ \\
\hline Mississippi & Feb-19 & $11.00 \%$ & $\$ 330,773$ & $12.00 \%$ \\
\hline Mississippi & Mar-19 & $15.10 \%$ & $\$ 587,847$ & $12.00 \%$ \\
\hline Mississippi & Apr-19 & $10.70 \%$ & $\$ 246,940$ & $12.00 \%$ \\
\hline Mississippi & May-19 & $6.80 \%$ & $\$ 143,036$ & $12.00 \%$ \\
\hline Mississippi & Jun-19 & $10.70 \%$ & $\$ 195,014$ & $12.00 \%$ \\
\hline Mississippi & Jul-19 & $7.90 \%$ & $\$ 126,453$ & $12.00 \%$ \\
\hline Mississippi & Aug-19 & $14.50 \%$ & $\$ 346,122$ & $12.00 \%$ \\
\hline Mississippi & Sep-19 & $14.90 \%$ & $\$ 675,790$ & $12.00 \%$ \\
\hline Mississippi & Oct-19 & $25.60 \%$ & $\$ 1,475,443$ & $12.00 \%$ \\
\hline Mississippi & Nov-19 & $6.70 \%$ & $\$ 454,088$ & $12.00 \%$ \\
\hline Mississippi & Dec-19 & $7.10 \%$ & $\$ 417,470$ & $12.00 \%$ \\
\hline Mississippi & Jan-20 & $10.30 \%$ & $\$ 556,556$ & $12.00 \%$ \\
\hline Mississippi & Feb-20 & $6.10 \%$ & $\$ 252,694$ & $12.00 \%$ \\
\hline Mississippi & Mar-20 & $6.00 \%$ & $\$ 77,838$ & $12.00 \%$ \\
\hline Mississippi & Apr-20 & N/A & N/A & N/A \\
\hline Mississippi & May-20 & $37.10 \%$ & $\$ 10,524$ & $12.00 \%$ \\
\hline Mississippi & Jun-20 & $-4.00 \%$ & N/A & N/A \\
\hline Mississippi & Jul-20 & $5.80 \%$ & $\$ 6,058$ & $12.00 \%$ \\
\hline
\end{tabular}

\section{Table A.5}

\begin{tabular}{|l|r|r|r|}
\hline \multicolumn{1}{|c}{ State } & \multicolumn{1}{c}{ Month } & \multicolumn{1}{c|}{ Handle } & \multicolumn{1}{c|}{ Revenue } \\
\hline Nevada & Jun-18 & $\$ 286,548,295$ & $\$ 20,173,000$ \\
\hline Nevada & Jul-18 & $\$ 244,638,554$ & $\$ 4,061,000$ \\
\hline Nevada & Aug-18 & $\$ 247,622,790$ & $\$ 12,604,000$ \\
\hline Nevada & Sep-18 & $\$ 571,034,483$ & $\$ 56,304,000$ \\
\hline Nevada & Oct-18 & $\$ 528,568,873$ & $\$ 29,547,000$ \\
\hline Nevada & Nov-18 & $\$ 581,070,664$ & $\$ 27,136,000$ \\
\hline Nevada & Dec-18 & $\$ 561,859,873$ & $\$ 44,106,000$ \\
\hline
\end{tabular}




\begin{tabular}{|c|c|c|c|c|}
\hline Nevada & Jan-19 & $\$ 497,482,993$ & & $\$ 14,626,000$ \\
\hline Nevada & Feb-19 & $\$ 458,591,549$ & & $\$ 35,816,000$ \\
\hline Nevada & Mar-19 & $\$ 596,752,294$ & & $\$ 32,523,000$ \\
\hline Nevada & Apr-19 & $\$ 328,121,212$ & & $\$ 21,656,000$ \\
\hline Nevada & May-19 & $\$ 317,380,282$ & & $\$ 11,267,000$ \\
\hline Nevada & Jun-19 & $\$ 322,077,670$ & & $\$ 16,587,000$ \\
\hline Nevada & Jul-19 & $\$ 235,659,955$ & & $\$ 10,534,000$ \\
\hline Nevada & Aug-19 & $\$ 287,757,296$ & & $\$ 18,733,000$ \\
\hline Nevada & Sep-19 & $\$ 546,358,867$ & & $\$ 52,068,000$ \\
\hline Nevada & Oct-19 & $\$ 543,552,781$ & & $\$ 47,887,000$ \\
\hline Nevada & Nov-19 & $\$ 614,118,812$ & & $\$ 31,013,000$ \\
\hline Nevada & Dec-19 & $\$ 571,179,245$ & & $\$ 36,327,000$ \\
\hline Nevada & Jan-20 & $\$ 502,543,641$ & & $\$ 20,152,000$ \\
\hline Nevada & Feb-20 & $\$ 489,105,725$ & & $\$ 38,064,000$ \\
\hline Nevada & Mar-20 & $\$ 141,108,201$ & & $\$ 1,455,000$ \\
\hline Nevada & Apr-May & $\$ 56,263,737$ & & $\$ 2,669,000$ \\
\hline Nevada & Jun-20 & $\$ 78,152,387$ & & $(\$ 483,000)$ \\
\hline Nevada & Jul-20 & $\$ 165,552,387$ & & $\$ 6,295,000$ \\
\hline State & Month & Hold & Taxes & Tax Rate \\
\hline Nevada & Jun-18 & $7.04 \%$ & $\$ 1,361,678$ & $6.75 \%$ \\
\hline Nevada & Jul-18 & $1.66 \%$ & $\$ 274,118$ & $6.75 \%$ \\
\hline Nevada & Aug-18 & $5.09 \%$ & $\$ 850,770$ & $6.75 \%$ \\
\hline Nevada & Sep-18 & $9.86 \%$ & $\$ 3,800,520$ & $6.75 \%$ \\
\hline Nevada & Oct-18 & $5.59 \%$ & $\$ 1,994,423$ & $6.75 \%$ \\
\hline Nevada & Nov-18 & $4.67 \%$ & $\$ 1,831,680$ & $6.75 \%$ \\
\hline Nevada & Dec-18 & $7.85 \%$ & $\$ 2,977,155$ & $6.75 \%$ \\
\hline Nevada & Jan-19 & $2.94 \%$ & $\$ 987,255$ & $6.75 \%$ \\
\hline Nevada & Feb-19 & $7.81 \%$ & $\$ 2,417,580$ & $6.75 \%$ \\
\hline Nevada & Mar-19 & $5.45 \%$ & $\$ 2,195,303$ & $6.75 \%$ \\
\hline Nevada & Apr-19 & $6.60 \%$ & $\$ 1,461,780$ & $6.75 \%$ \\
\hline Nevada & May-19 & $3.55 \%$ & $\$ 760,523$ & $6.75 \%$ \\
\hline Nevada & Jun-19 & $5.15 \%$ & $\$ 1,119,623$ & $6.75 \%$ \\
\hline Nevada & Jul-19 & $4.47 \%$ & $\$ 711,045$ & $6.75 \%$ \\
\hline Nevada & Aug-19 & $6.51 \%$ & $\$ 1,264,478$ & $6.75 \%$ \\
\hline Nevada & Sep-19 & $7.39 \%$ & $\$ 3,514,590$ & $6.75 \%$ \\
\hline Nevada & Oct-19 & $8.81 \%$ & $\$ 3,232,373$ & $6.75 \%$ \\
\hline Nevada & Nov-19 & $5.05 \%$ & $\$ 2,093,378$ & $6.75 \%$ \\
\hline Nevada & Dec-19 & $6.36 \%$ & $\$ 2,452,073$ & $6.75 \%$ \\
\hline
\end{tabular}




\begin{tabular}{|l|r|r|r|r|}
\hline Nevada & Jan-20 & $4.01 \%$ & $\$ 1,360,260$ & $6.75 \%$ \\
\hline Nevada & Feb-20 & $7.78 \%$ & $\$ 2,569,320$ & $6.75 \%$ \\
\hline Nevada & Mar-20 & $1.03 \%$ & $\$ 98,213$ & $6.75 \%$ \\
\hline Nevada & Apr-May & $4.74 \%$ & $\$ 180,158$ & $6.75 \%$ \\
\hline Nevada & Jun-20 & $-0.62 \%$ & N/A & N/A \\
\hline Nevada & Jul-20 & $3.80 \%$ & $\$ 424,913$ & $6.75 \%$ \\
\hline
\end{tabular}

\section{Table A.6}

\begin{tabular}{|c|c|c|c|c|}
\hline State & Month & Handle & \multicolumn{2}{|c|}{ Revenue } \\
\hline Rhode Island & Nov-18 & $\$ 682,714$ & & $\$ 72,997$ \\
\hline Rhode Island & Dec-18 & $\$ 13,087,999$ & & $\$ 957,913$ \\
\hline Rhode Island & Jan-19 & $\$ 19,051,125$ & & $\$ 159,978$ \\
\hline Rhode Island & Feb-19 & $\$ 20,686,618$ & & $(\$ 890,623)$ \\
\hline Rhode Island & Mar-19 & $\$ 23,582,716$ & & $\$ 1,548,230$ \\
\hline Rhode Island & Apr-19 & $\$ 16,859,818$ & & $\$ 1,970,110$ \\
\hline Rhode Island & May-19 & $\$ 18,900,152$ & & $\$ 899,165$ \\
\hline Rhode Island & Jun-19 & $\$ 14,736,667$ & & $\$ 2,149,999$ \\
\hline Rhode Island & Jul-19 & $\$ 8,321,947$ & & $\$ 827,579$ \\
\hline Rhode Island & Aug-19 & $\$ 10,060,066$ & & $\$ 851,788$ \\
\hline Rhode Island & Sep-19 & $\$ 22,195,789$ & & $\$ 2,516,059$ \\
\hline Rhode Island & Oct-19 & $\$ 28,281,024$ & & $\$ 2,457,136$ \\
\hline Rhode Island & Nov-19 & $\$ 31,465,062$ & & $\$ 2,745,518$ \\
\hline Rhode Island & Dec-19 & $\$ 31,670,511$ & & $\$ 2,571,755$ \\
\hline Rhode Island & Jan-20 & $\$ 26,939,692$ & & $\$ 3,279,241$ \\
\hline Rhode Island & Feb-20 & $\$ 28,147,862$ & & $\$ 2,323,432$ \\
\hline Rhode Island & Mar-20 & $\$ 8,949,157$ & & $\$ 841,767$ \\
\hline Rhode Island & Apr-20 & $\$ 591,377$ & & $\$ 27,381$ \\
\hline Rhode Island & May-20 & $\$ 1,533,114$ & & $\$ 163,472$ \\
\hline Rhode Island & Jun-20 & $\$ 2,032,803$ & & $\$ 101,328$ \\
\hline Rhode Island & Jul-20 & $\$ 6,738,626$ & & $\$ 351,425$ \\
\hline State & Month & Hold & Taxes & Tax Rate \\
\hline Rhode Island & Nov-18 & $10.70 \%$ & $\$ 37,228$ & $51.00 \%$ \\
\hline Rhode Island & Dec-18 & $7.30 \%$ & $\$ 488,536$ & $51.00 \%$ \\
\hline Rhode Island & Jan-19 & $0.80 \%$ & $\$ 81,589$ & $51.00 \%$ \\
\hline Rhode Island & Feb-19 & $-4.30 \%$ & $(\$ 454,218)$ & $51.00 \%$ \\
\hline Rhode Island & Mar-19 & $6.60 \%$ & $\$ 789,597$ & $51.00 \%$ \\
\hline Rhode Island & Apr-19 & $11.70 \%$ & $\$ 1,004,756$ & $51.00 \%$ \\
\hline
\end{tabular}




\begin{tabular}{|l|r|r|r|r|}
\hline Rhode Island & May-19 & $4.80 \%$ & $\$ 458,574$ & $51.00 \%$ \\
\hline Rhode Island & Jun-19 & $14.60 \%$ & $\$ 1,096,499$ & $51.00 \%$ \\
\hline Rhode Island & Jul-19 & $9.90 \%$ & $\$ 422,065$ & $51.00 \%$ \\
\hline Rhode Island & Aug-19 & $8.50 \%$ & $\$ 434,412$ & $51.00 \%$ \\
\hline Rhode Island & Sep-19 & $11.30 \%$ & $\$ 1,283,190$ & $51.00 \%$ \\
\hline Rhode Island & Oct-19 & $8.70 \%$ & $\$ 1,253,139$ & $51.00 \%$ \\
\hline Rhode Island & Nov-19 & $8.70 \%$ & $\$ 1,400,214$ & $51.00 \%$ \\
\hline Rhode Island & Dec-19 & $8.10 \%$ & $\$ 1,311,595$ & $51.00 \%$ \\
\hline Rhode Island & Jan-20 & $12.20 \%$ & $\$ 1,672,413$ & $51.00 \%$ \\
\hline Rhode Island & Feb-20 & $8.30 \%$ & $\$ 1,184,950$ & $51.00 \%$ \\
\hline Rhode Island & Mar-20 & $9.40 \%$ & $\$ 429,301$ & $51.00 \%$ \\
\hline Rhode Island & Apr-20 & $4.60 \%$ & $\$ 13,964$ & $51.00 \%$ \\
\hline Rhode Island & May-20 & $10.70 \%$ & $\$ 83,371$ & $51.00 \%$ \\
\hline Rhode Island & Jun-20 & $5.00 \%$ & $\$ 51,677$ & $51.00 \%$ \\
\hline Rhode Island & Jul-20 & $5.20 \%$ & $\$ 179,277$ & $51.00 \%$ \\
\hline
\end{tabular}

Table A.7

\begin{tabular}{|c|c|c|c|}
\hline State & Month & Handle & Revenue \\
\hline West Virginia & Sep-18 & $\$ 7,322,255$ & $\$ 2,129,235$ \\
\hline West Virginia & Oct-18 & $\$ 9,735,874$ & $\$ 1,010,246$ \\
\hline West Virginia & Nov-18 & $\$ 16,045,602$ & $\$ 1,161,375$ \\
\hline West Virginia & Dec-18 & $\$ 13,322,131$ & $\$ 2,247,152$ \\
\hline West Virginia & Jan-19 & $\$ 22,431,187$ & $\$ 1,746,233$ \\
\hline West Virginia & Feb-19 & $\$ 16,609,597$ & $\$ 171,089$ \\
\hline West Virginia & Mar-19 & $\$ 13,850,999$ & $\$ 1,597,521$ \\
\hline West Virginia & Apr-19 & $\$ 10,334,722$ & $\$ 554,880$ \\
\hline West Virginia & May-19 & $\$ 10,704,030$ & $\$ 937,065$ \\
\hline West Virginia & Jun-19 & $\$ 7,634,979$ & $\$ 379,228$ \\
\hline West Virginia & Jul-19 & $\$ 5,851,318$ & $\$ 682,213$ \\
\hline West Virginia & Aug-19 & $\$ 12,656,911$ & $\$ 1,549,585$ \\
\hline West Virginia & Sep-19 & $\$ 25,620,078$ & $\$ 3,755,760$ \\
\hline West Virginia & Oct-19 & $\$ 37,022,626$ & $\$ 3,156,830$ \\
\hline West Virginia & Nov-19 & $\$ 32,968,353$ & $\$ 2,289,056$ \\
\hline West Virginia & Dec-19 & $\$ 30,342,334$ & $\$ 2,322,915$ \\
\hline West Virginia & Jan-20 & $\$ 44,253,798$ & $\$ 3,651,273$ \\
\hline West Virginia & Feb-20 & $\$ 39,618,767$ & $(\$ 626,470)$ \\
\hline West Virginia & Mar-20 & $\$ 14,705,300$ & $\$ 1,101,454$ \\
\hline
\end{tabular}




\begin{tabular}{|c|c|c|c|c|}
\hline West Virginia & Apr-20 & $\$ 2,965,302$ & & $\$ 155,058$ \\
\hline West Virginia & May-20 & $\$ 4,971,928$ & & $\$ 541,188$ \\
\hline West Virginia & Jun-20 & $\$ 6,338,618$ & & $\$ 567,836$ \\
\hline West Virginia & Jul-20 & $\$ 15,853,463$ & & $\$ 1,573,845$ \\
\hline West Virginia & Aug-20 & $\$ 45,897,001$ & & $\$ 2,337,229$ \\
\hline State & Month & Hold & Taxes & Tax Rate \\
\hline West Virginia & Sep-18 & $29.10 \%$ & $\$ 212,924$ & $10.00 \%$ \\
\hline West Virginia & Oct-18 & $10.40 \%$ & $\$ 101,025$ & $10.00 \%$ \\
\hline West Virginia & Nov-18 & $7.20 \%$ & $\$ 116,138$ & $10.00 \%$ \\
\hline West Virginia & Dec-18 & $16.90 \%$ & $\$ 224,715$ & $10.00 \%$ \\
\hline West Virginia & Jan-19 & $7.80 \%$ & $\$ 174,623$ & $10.00 \%$ \\
\hline West Virginia & Feb-19 & $1.00 \%$ & $\$ 17,109$ & $10.00 \%$ \\
\hline West Virginia & Mar-19 & $11.50 \%$ & $\$ 159,752$ & $10.00 \%$ \\
\hline West Virginia & Apr-19 & $5.40 \%$ & $\$ 55,488$ & $10.00 \%$ \\
\hline West Virginia & May-19 & $8.80 \%$ & $\$ 93,707$ & $10.00 \%$ \\
\hline West Virginia & Jun-19 & $5.00 \%$ & $\$ 37,923$ & $10.00 \%$ \\
\hline West Virginia & Jul-19 & $11.70 \%$ & $\$ 68,221$ & $10.00 \%$ \\
\hline West Virginia & Aug-19 & $12.20 \%$ & $\$ 154,959$ & $10.00 \%$ \\
\hline West Virginia & Sep-19 & $14.70 \%$ & $\$ 375,576$ & $10.00 \%$ \\
\hline West Virginia & Oct-19 & $8.50 \%$ & $\$ 315,683$ & $10.00 \%$ \\
\hline West Virginia & Nov-19 & $6.90 \%$ & $\$ 228,906$ & $10.00 \%$ \\
\hline West Virginia & Dec-19 & $7.70 \%$ & $\$ 232,292$ & $10.00 \%$ \\
\hline West Virginia & Jan-20 & $8.30 \%$ & $\$ 365,127$ & $10.00 \%$ \\
\hline West Virginia & Feb-20 & $-1.60 \%$ & $(\$ 62,647)$ & $10.00 \%$ \\
\hline West Virginia & Mar-20 & $7.50 \%$ & $\$ 110,145$ & $10.00 \%$ \\
\hline West Virginia & Apr-20 & $5.20 \%$ & $\$ 15,506$ & $10.00 \%$ \\
\hline West Virginia & May-20 & $10.90 \%$ & $\$ 54,119$ & $10.00 \%$ \\
\hline West Virginia & Jun-20 & $9.00 \%$ & $\$ 56,784$ & $10.00 \%$ \\
\hline West Virginia & Jul-20 & $9.90 \%$ & $\$ 157,385$ & $10.00 \%$ \\
\hline West Virginia & Aug-20 & $5.10 \%$ & $\$ 233,723$ & $10.00 \%$ \\
\hline
\end{tabular}

\section{Table A.8}

\begin{tabular}{|r|r|r|r|}
\hline \multicolumn{1}{|c}{ State } & \multicolumn{1}{c}{ Month } & \multicolumn{1}{c|}{ Handle } & \multicolumn{1}{r|}{ Revenue } \\
\hline New York & Jul-19 & N/A & $\$ 349,468$ \\
\hline New York & Aug-19 & N/A & $\$ 828,152$ \\
\hline New York & Sep-19 & N/A & $\$ 2,283,865$ \\
\hline
\end{tabular}




\begin{tabular}{|c|c|c|c|c|}
\hline New York & Oct-19 & N/A & & $\$ 2,233,227$ \\
\hline New York & Nov-19 & N/A & & $\$ 1,308,296$ \\
\hline New York & Dec-19 & N/A & & $\$ 780,418$ \\
\hline New York & Jan-20 & N/A & & $\$ 1,943,361$ \\
\hline New York & Feb-20 & N/A & & $(\$ 179,593)$ \\
\hline New York & Mar-20 & N/A & & $\$ 99,514$ \\
\hline State & Month & Hold & Taxes & Tax Rate \\
\hline New York & Jul-19 & N/A & $\$ 34,947$ & $10.00 \%$ \\
\hline New York & Aug-19 & N/A & $\$ 82,815$ & $10.00 \%$ \\
\hline New York & Sep-19 & N/A & $\$ 228,387$ & $10.00 \%$ \\
\hline New York & Oct-19 & N/A & $\$ 223,323$ & $10.00 \%$ \\
\hline New York & Nov-19 & N/A & $\$ 130,830$ & $10.00 \%$ \\
\hline New York & Dec-19 & N/A & $\$ 78,042$ & $10.00 \%$ \\
\hline New York & Jan-20 & N/A & $\$ 194,336$ & $10.00 \%$ \\
\hline New York & Feb-20 & N/A & N/A & N/A \\
\hline New York & Mar-20 & N/A & $\$ 9,951$ & $10.00 \%$ \\
\hline
\end{tabular}

\section{Table A.9}

\begin{tabular}{|c|c|c|c|c|}
\hline State & Month & Handle & \multicolumn{2}{|c|}{ Revenue } \\
\hline Iowa & Aug-19 & $\$ 8,756,246$ & & $\$ 2,161,688$ \\
\hline Iowa & Sep-19 & $\$ 38,528,921$ & & $\$ 4,956,347$ \\
\hline Iowa & Oct-19 & $\$ 46,500,443$ & & $\$ 5,658,243$ \\
\hline Iowa & Nov-19 & $\$ 59,344,806$ & & $\$ 3,599,750$ \\
\hline Iowa & Dec-19 & $\$ 59,258,838$ & & $\$ 2,904,257$ \\
\hline Iowa & Jan-20 & $\$ 58,027,141$ & & $\$ 3,324,794$ \\
\hline Iowa & Feb-20 & $\$ 56,920,783$ & & $\$ 755,334$ \\
\hline Iowa & Mar-20 & $\$ 19,576,985$ & & $\$ 1,171,164$ \\
\hline Iowa & Apr-20 & $\$ 1,568,497$ & & $\$ 150,331$ \\
\hline Iowa & May-20 & $\$ 6,976,637$ & & $\$ 501,062$ \\
\hline Iowa & Jun-20 & $\$ 12,711,201$ & & $\$ 620,740$ \\
\hline Iowa & Jul-20 & $\$ 22,859,622$ & & $\$ 2,244,021$ \\
\hline State & Month & Hold & Taxes & Tax Rate \\
\hline Iowa & Aug-19 & $25.20 \%$ & $\$ 145,914$ & $6.75 \%$ \\
\hline Iowa & Sep-19 & $12.90 \%$ & $\$ 334,553$ & $6.75 \%$ \\
\hline Iowa & Oct-19 & $12.20 \%$ & $\$ 381,931$ & $6.75 \%$ \\
\hline Iowa & Nov-19 & $6.10 \%$ & $\$ 242,983$ & $6.75 \%$ \\
\hline
\end{tabular}




\begin{tabular}{|l|r|r|r|r|}
\hline Iowa & Dec-19 & $4.90 \%$ & $\$ 196,037$ & $6.75 \%$ \\
\hline Iowa & Jan-20 & $5.60 \%$ & $\$ 218,349$ & $6.75 \%$ \\
\hline Iowa & Feb-20 & $1.30 \%$ & $\$ 50,985$ & $6.75 \%$ \\
\hline Iowa & Mar-20 & $6.00 \%$ & $\$ 79,171$ & $6.75 \%$ \\
\hline Iowa & Apr-20 & $9.60 \%$ & $\$ 9,502$ & $6.75 \%$ \\
\hline Iowa & May-20 & $7.20 \%$ & $\$ 32,111$ & $6.75 \%$ \\
\hline Iowa & Jun-20 & $4.90 \%$ & $\$ 42,033$ & $6.75 \%$ \\
\hline Iowa & Jul-20 & $9.80 \%$ & $\$ 151,919$ & $6.75 \%$ \\
\hline
\end{tabular}

Table A.10

\begin{tabular}{|c|c|c|c|c|}
\hline State & Month & Handle & \multicolumn{2}{|c|}{ Revenue } \\
\hline Indiana & Sep-19 & $\$ 35,215,416$ & & $\$ 8,558,974$ \\
\hline Indiana & Oct-19 & $\$ 91,697,393$ & & $\$ 11,538,533$ \\
\hline Indiana & Nov-19 & $\$ 147,276,912$ & & $\$ 10,593,321$ \\
\hline Indiana & Dec-19 & $\$ 161,808,924$ & & $\$ 12,068,114$ \\
\hline Indiana & Jan-20 & $\$ 171,049,250$ & & $\$ 12,223,222$ \\
\hline Indiana & Feb-20 & $\$ 187,186,221$ & & $\$ 10,381,954$ \\
\hline Indiana & Mar-20 & $\$ 74,818,802$ & & $\$ 5,495,640$ \\
\hline Indiana & Apr-20 & $\$ 26,304,128$ & & $\$ 1,559,884$ \\
\hline Indiana & May-20 & $\$ 37,334,940$ & & $\$ 3,179,968$ \\
\hline Indiana & Jun-20 & $\$ 29,783,580$ & & $\$ 2,922,108$ \\
\hline Indiana & Jul-20 & $\$ 70,876,622$ & & $\$ 6,658,465$ \\
\hline State & Month & Hold & Taxes & Tax Rate \\
\hline Indiana & Sep-19 & $24.30 \%$ & $\$ 813,103$ & $6.75 \%$ \\
\hline Indiana & Oct-19 & $12.60 \%$ & $\$ 1,096,161$ & $6.75 \%$ \\
\hline Indiana & Nov-19 & $7.20 \%$ & $\$ 1,006,365$ & $6.75 \%$ \\
\hline Indiana & Dec-19 & $7.50 \%$ & $\$ 1,146,471$ & $6.75 \%$ \\
\hline Indiana & Jan-20 & $7.10 \%$ & $\$ 1,161,206$ & $6.75 \%$ \\
\hline Indiana & Feb-20 & $5.50 \%$ & $\$ 986,286$ & $6.75 \%$ \\
\hline Indiana & Mar-20 & $7.30 \%$ & $\$ 522,085$ & $6.75 \%$ \\
\hline Indiana & Apr-20 & $5.90 \%$ & $\$ 148,189$ & $6.75 \%$ \\
\hline Indiana & May-20 & $8.50 \%$ & $\$ 302,097$ & $6.75 \%$ \\
\hline Indiana & Jun-20 & $9.80 \%$ & $\$ 277,601$ & $6.75 \%$ \\
\hline Indiana & Jul-20 & $9.40 \%$ & $\$ 632,554$ & $6.75 \%$ \\
\hline
\end{tabular}


Appendix B: Summary Statistics and Fundamental Assumptions

\section{Summary Statistics}

\section{Summary Statistics}

\begin{tabular}{|l|r|r|r|}
\hline \multicolumn{4}{|c}{$\begin{array}{c}\text { Percent } \\
\text { Mortgages } \\
\text { Delinquent } \\
\text { 30-89 Days }\end{array}$} \\
\hline Mean & 2.544 & 0.040 & 0.068 \\
\hline $\begin{array}{l}\text { Standard } \\
\text { Error }\end{array}$ & 0.012 & 0.003 & 0.005 \\
\hline Median & 2.400 & 0.000 & 0.000 \\
\hline Mode & 2.200 & 0.000 & 0.000 \\
\hline $\begin{array}{l}\text { Standard } \\
\text { Deviation }\end{array}$ & 0.963 & 0.196 & 0.364 \\
\hline $\begin{array}{l}\text { Sample } \\
\text { Variance }\end{array}$ & 0.927 & 0.038 & 0.133 \\
\hline Kurtosis & 0.570 & 20.131 & 34.020 \\
\hline Skewness & 0.731 & 4.704 & 5.761 \\
\hline Range & 6.200 & 1.000 & 3.000 \\
\hline Minimum & 0.800 & 0.000 & 0.000 \\
\hline Maximum & 7.000 & 1.000 & 3.000 \\
\hline Sum & $15,181.3$ & 238.000 & 404.000 \\
\hline Count & 5,967 & 5,967 & 5,967 \\
\hline & & & \\
\hline
\end{tabular}




\begin{tabular}{|l|l|r|r|}
\hline \multicolumn{2}{|c|}{ Amount Wagered } & \multicolumn{1}{c|}{ GDP } & Unemployment \\
\hline Mean & $2,077,284.9$ & $547,606.2$ & 5.875 \\
\hline $\begin{array}{l}\text { Standard } \\
\text { Error }\end{array}$ & $352,370.7$ & $5,712.9$ & 0.029 \\
\hline Median & 0.000 & $203,430.6$ & 5.400 \\
\hline Mode & 0.000 & $170,131.0$ & 4.000 \\
\hline $\begin{array}{l}\text { Standard } \\
\text { Deviation }\end{array}$ & $27,219,350.8$ & $441,300.1$ & 2.235 \\
\hline $\begin{array}{l}\text { Sample } \\
\text { Variance }\end{array}$ & $7.4 \mathrm{E}+14$ & $1.947 \mathrm{E}+11$ & 4.995 \\
\hline Kurtosis & 277.578 & & -0.132 \\
\hline Skewness & 16.001 & 11.870 & 0.672 \\
\hline Range & $6 . \mathrm{E}+08$ & 3.131 & 11.800 \\
\hline Minimum & 0.000 & $3,128,739.6$ & 2.100 \\
\hline Maximum & $596,752,294$ & $26,484.1$ & 13.900 \\
\hline Sum & $12,395,159,002$ & $2,074,166,243.7$ & $35,054.400$ \\
\hline Count & 5,967 & 5,967 & 5,967 \\
\hline
\end{tabular}

\section{Normality Assumption}

Each of the below histograms outlines a bell curve, showing strong support for the normality assumption. 200

200 For the importance of the normality assumption to parametric statistical tests (including many regressions) and methods of testing the assumption, see Peter SAmuels \& Ellen Marshall, Statstutor, Checking Normality For Parametric Tests in SPSS (2020), https://www.sheffield.ac.uk/polopoly_fs/1.885111!/file/61_Normality_Check .pdf [https://perma.cc/2SJE-MFQV]. 
Figure B.1

\section{Model One: Histogram of Residuals}

1200

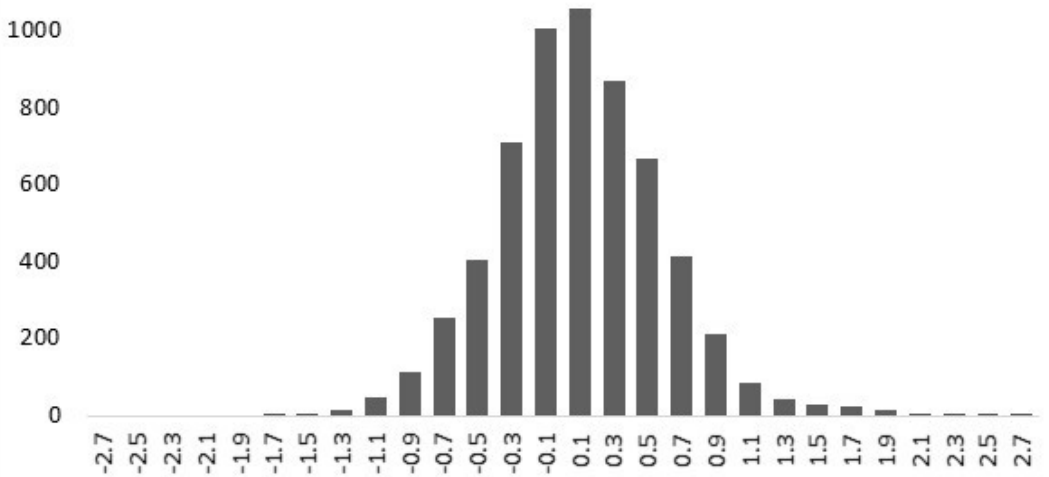

Figure B.2

\section{Model Two: Histogram of Residuals}

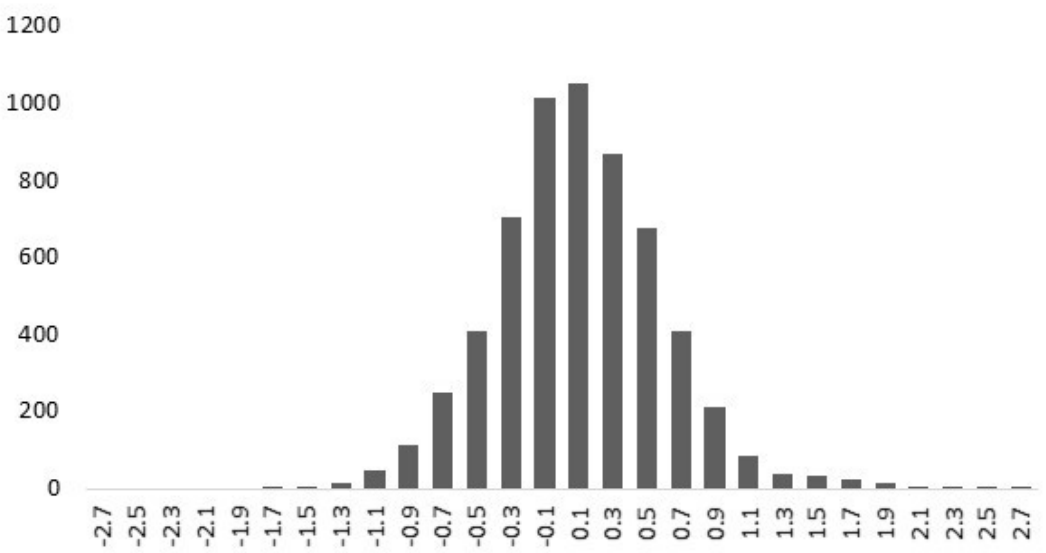


Figure B.3

\section{Model Three: Histogram of Residuals}

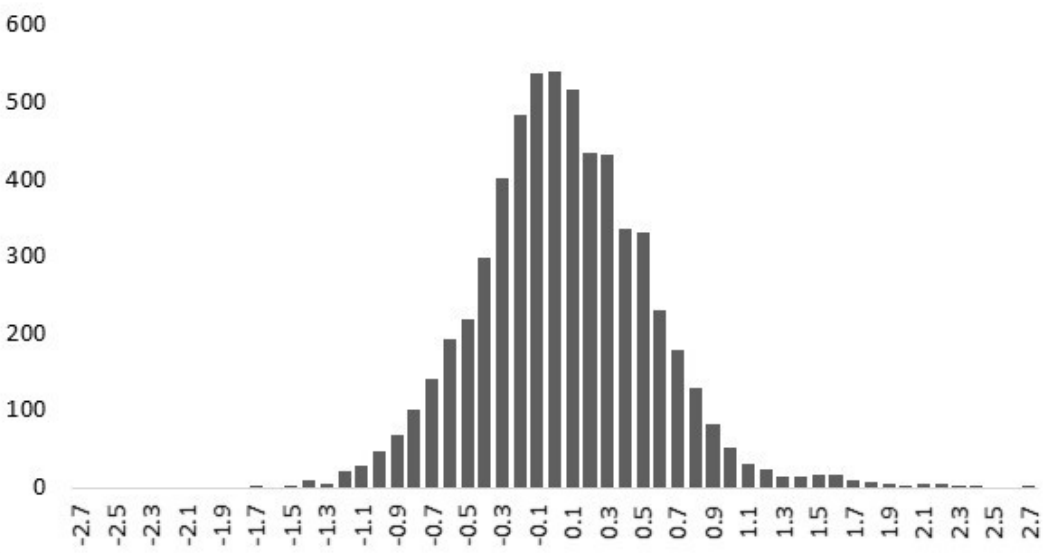

\section{Linearity Assumption}

As discussed in the limitations section, each model displays heteroskedasticity. ${ }^{201}$ Nevertheless, because the residuals cluster around zero, plots of residuals against the model's fitted values support the usual assumption that the dependent variable in my models has a linear relationship with the independent variables. 202

201 See supra notes 161-70 and accompanying text.

202 See FARAWAY, supra note 100, at 59 fig.4.1 (giving plots illustrating heteroskedasticity and linearity issues). 
Figure B.4

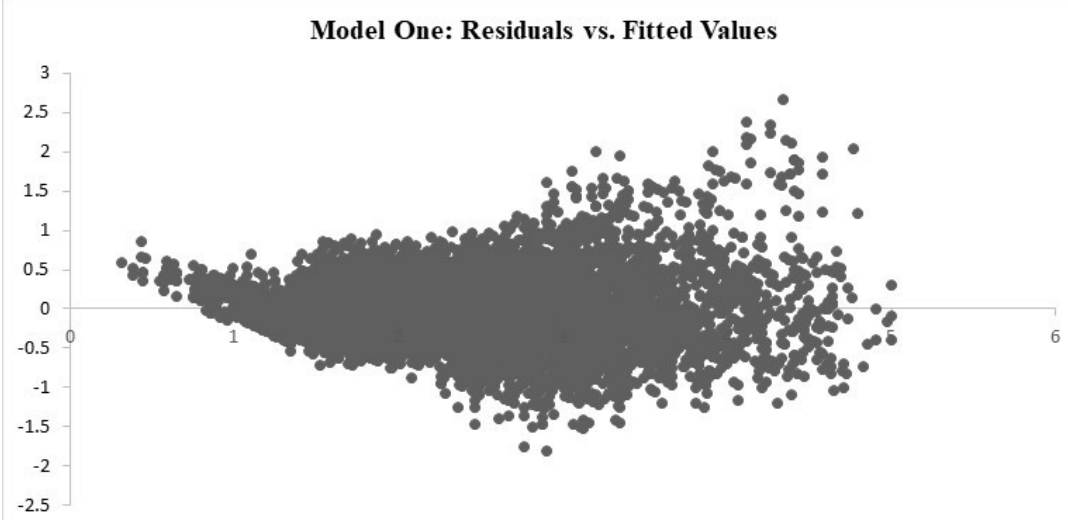

Figure B.5

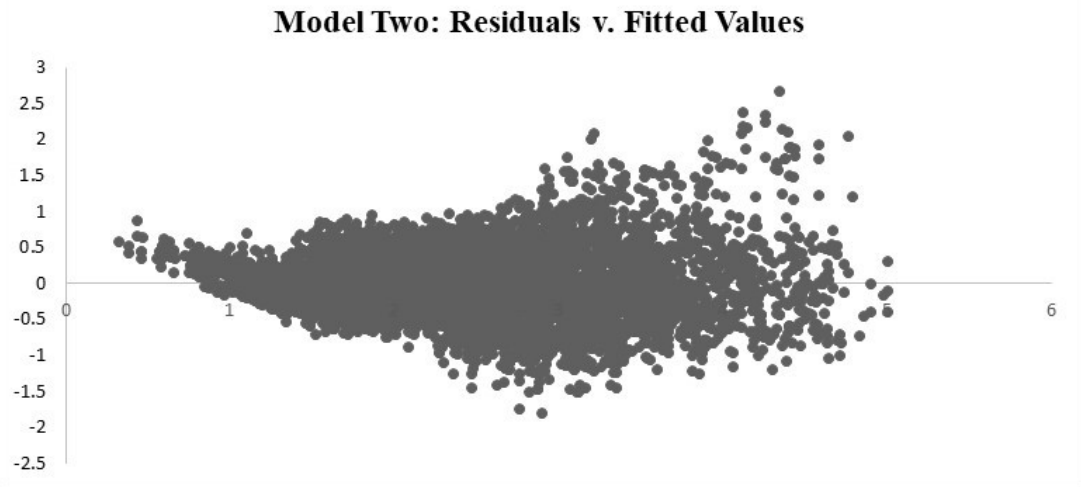

Figure B.6

Model Three: Residuals v. Fitted Values

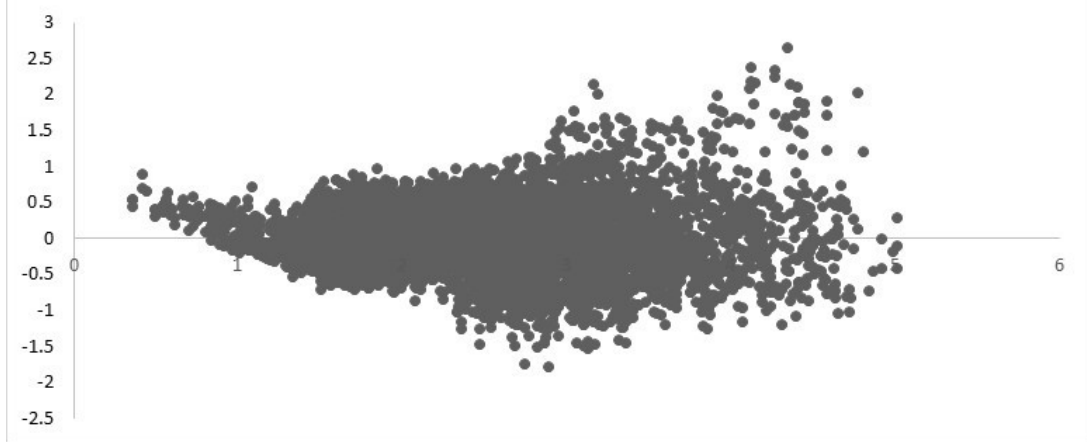




\section{Appendix C: Regional Classifications}

\section{Table C.1}

\begin{tabular}{|c|c|}
\hline State & Region \\
\hline Alaska & Far West \\
\hline California & Far West \\
\hline Hawaii & Far West \\
\hline Nevada & Far West \\
\hline Oregon & Far West \\
\hline Washington & Far West \\
\hline Illinois & Great Lakes \\
\hline Indiana & Great Lakes \\
\hline Michigan & Great Lakes \\
\hline Ohio & Great Lakes \\
\hline Wisconsin & Great Lakes \\
\hline Delaware & Mideast \\
\hline District of Columbia & Mideast \\
\hline Maryland & Mideast \\
\hline New Jersey & Mideast \\
\hline New York & Mideast \\
\hline Pennsylvania & Mideast \\
\hline Connecticut & New England \\
\hline Maine & New England \\
\hline Massachusetts & New England \\
\hline New Hampshire & New England \\
\hline Rhode Island & New England \\
\hline Vermont & New England \\
\hline Iowa & Plains \\
\hline Kansas & Plains \\
\hline Minnesota & Plains \\
\hline Missouri & Plains \\
\hline Nebraska & Plains \\
\hline North Dakota & Plains \\
\hline South Dakota & Plains \\
\hline Colorado & Rocky Mountain \\
\hline Idaho & Rocky Mountain \\
\hline
\end{tabular}


[Vol. 2020

\begin{tabular}{|l|r|}
\hline Montana & Rocky Mountain \\
\hline Utah & Rocky Mountain \\
\hline Wyoming & Rocky Mountain \\
\hline Alabama & Southeast \\
\hline Arkansas & Southeast \\
\hline Florida & Southeast \\
\hline Georgia & Southeast \\
\hline Kentucky & Southeast \\
\hline Louisiana & Southeast \\
\hline Mississippi & Southeast \\
\hline North Carolina & Southeast \\
\hline South Carolina & Southeast \\
\hline Tennessee & Southeast \\
\hline Virginia & Southeast \\
\hline West Virginia & Southeast \\
\hline Arizona & Southwest \\
\hline New Mexico & Southwest \\
\hline Oklahoma & Southwest \\
\hline Texas & Southwest \\
\hline
\end{tabular}

